\title{
Descripción teórica y experimental del equilibrio de adsorción de soluciones iónicas en la superficie de los sistemas $\gamma-\mathrm{Al}_{2} \mathrm{O}_{3}$ y $\mathrm{MoO}_{3} / \gamma-\mathrm{Al}_{2} \mathrm{O}_{3}$
}

\author{
Fiderman Machuca-Martínez", José L. G. Fierro**§ \\ *Laboratorio de Investigación en Catálisis y Procesos. Escuela de Ingeniería Química, Universidad \\ del Valle, A.A. 25360. Cali, Colombia. \\ **Instituto de Catálisis y Petroleoquímica, CSIC, Cantoblanco, 28049 Madrid, España. \\ §e-mail:jlgfierro@icp.csic.es
}

(Recibido: Enero 13 de 2010- Aceptado: Abril 3 de 2010)

\section{Resumen}

Se estudiaron las isotermas de adsorción en equilibrio de iones Mo, Co y Pt sobre $\gamma-\mathrm{Al}_{2} \mathrm{O}_{3}$ y iones Co y Pt sobre $\mathrm{MoO}_{3} / \gamma-\mathrm{Al}_{2} \mathrm{O}_{3}$. Los catalizadores molibdeno alúmina para los ensayos de adsorción fueron preparados por impregnación de los soportes de alúmina con heptamolibdato de amonio. Los datos de equilibrio de adsorción fueron obtenidos a partir del proceso de adsorción liquido-sólido. Las curvas de adsorción fueron tipo L para los sistemas Mo y Co sobre $\gamma-\mathrm{Al}_{2} \mathrm{O}_{3}$ y $\mathrm{Co}(\mathrm{Pt})$ sobre $\mathrm{MoO}_{3} / \gamma-\mathrm{Al}_{2} \mathrm{O}_{3}$, mientras para el sistema $\mathrm{Pt}(\mathrm{Co})$ sobre $\mathrm{MoO}_{3} / \gamma-\mathrm{Al}_{2} \mathrm{O}_{3}$ fueron tipo S. Para el caso del molibdeno, se encontró que las especies en solución (tetraédricas y octaédricas) afectan la adsorción del molibdeno. La adsorción de iones $\mathrm{Co}$ (II) sobre alúmina o alúmina modificada no depende de la alúmina utilizada. La forma de las isotermas de adsorción de iones Co sobre $\mathrm{MoO}_{3} / \gamma-\mathrm{Al}_{2} \mathrm{O}_{3}$ parece ser modificada cuando los iones $\mathrm{Pt}(\mathrm{IV})$ están presentes simultáneamente. Los procesos de adsorción de especies de Pt dependen de la presencia de $\mathrm{Mo}(\mathrm{VI})$ y $\mathrm{Co}(\mathrm{II})$ en la superficie de los soportes. Se observó que la cantidad de Pt adsorbido sobre $\mathrm{MoO}_{3} / \gamma-\mathrm{Al}_{2} \mathrm{O}_{3}$ disminuye en presencia de iones $\mathrm{Co}$ (II) en solución. Finalmente, se calcularon los parámetros de adsorción en equilibrio de los sistemas $\mathrm{Mo}(\mathrm{VI})$ and $\mathrm{Co}(\mathrm{II})$ sobre $\gamma-\mathrm{Al}_{2} \mathrm{O}_{3}$ and $\mathrm{Co}(\mathrm{II}) \mathrm{y} / \mathrm{o} \mathrm{Pt}(\mathrm{IV})$ sobre $\mathrm{MoO}_{3} / \gamma-\mathrm{Al}_{2} \mathrm{O}_{3}$.

Palabras Claves: Adsorción en equilibrio, Adsorción líquido sólido, Isotermas de adsorción, Alúmina, Molibdeno, Platino, Cobalto, Preparación de catalizadores.

\section{Experimental and theoretical description of the equilibrium adsorption of metal ion solutions on the surface of $\gamma-\mathrm{Al}_{2} \mathrm{O}_{3}$ and $\mathrm{MoO}_{3} / \gamma-\mathrm{Al}_{2} \mathrm{O}_{3}$ systems}

\begin{abstract}
The equilibrium adsorption isotherms of Mo, Co and $\mathrm{Pt}$ species on $\gamma-\mathrm{Al}_{2} \mathrm{O}_{3}$ and $\mathrm{Co}$ and $\mathrm{Pt}$ on $\mathrm{MoO}_{3} /-\mathrm{Al}_{2} \mathrm{O}_{3}$ oxides were studied. The Molybdena-alumina catalysts for adsorption tests were prepared by impregnation of $\gamma-\mathrm{Al}_{2} \mathrm{O}_{3}$ supports with aqueous solutions of ammonium heptamolybdate. The equilibrium adsorption data were obtained from liquid-solid adsorption process. L-type shaped adsorption curves were found for $\mathrm{Mo}$ and $\mathrm{Co}$ on $\gamma-\mathrm{Al}_{2} \mathrm{O}_{3}$ and $\mathrm{Co}(\mathrm{Pt})$ on $\mathrm{MoO}_{3} / \gamma-\mathrm{Al}_{2} \mathrm{O}_{3}$ whereas S-shaped were found in the $\mathrm{Pt}(\mathrm{Co})$ on $\mathrm{MoO}_{3} / \gamma-\mathrm{Al}_{2} \mathrm{O}_{3}$ systems. In the Mo system, it was found that the molybdenum species in solution (tetrahedral and octahedral) affected the Mo adsorption. The adsorption of $\mathrm{Co}(\mathrm{II})$ ions over alumina or modified alumina did not depend on the alumina source. The shape of the Co adsorption isotherm on $\mathrm{MoO}_{3} / \gamma-\mathrm{Al}_{2} \mathrm{O}_{3}$ appeared to be modified when $\mathrm{Pt}(\mathrm{IV})$ ions were present simultaneously. The adsorption process for Pt species depended on the presence of $\mathrm{Mo}(\mathrm{VI})$ and $\mathrm{Co}(\mathrm{II})$ ions on the supports surface. It was observed that the amount of Pt adsorbed on the surface of the $\mathrm{MoO}_{3} / \gamma-\mathrm{Al}_{2} \mathrm{O}_{3}$ sample decreased in the presence of $\mathrm{Co}$ (II) ions in solution. Finally, the equilibrium parameters for the adsorption of $\mathrm{Mo}(\mathrm{VI})$ and $\mathrm{Co}(\mathrm{II})$ on $\gamma-\mathrm{Al}_{2} \mathrm{O}_{3}$ and $\mathrm{Co}$ (II) and/or $\mathrm{Pt}(\mathrm{IV})$ on $\mathrm{MoO}_{3} / \gamma-\mathrm{Al}_{2} \mathrm{O}_{3}$ were determined.
\end{abstract}

Keywords: Equilibrium adsorption, Liquid solid adsorption, Adsorption isotherms, Alumina, Molybdenum, Platinum, Cobalt, Catalysts preparation. 


\section{Introducción}

The need for better hydrotreating catalysts has promoted the research into new catalytic systems. The new generation noble metal-promoted $\mathrm{MoO}_{3} / \mathrm{Al}_{2} \mathrm{O}_{3}$ systems, noble metal $/ \mathrm{Al}_{2} \mathrm{O}_{3}$ and different combinations of these can exhibit different performances not only in hydrotreatment reactions of oil fractions but also in other reactions, i.e. isomerization and hydrogenation processes, NOx abatement, partial oxidation and olefin metathesis, Kubota et al. (2010), Achchar et al. (2009), Baldovino-Medrano et al. (2009), Chianelli et al. (2009), Roukoss et al. (2009), Eliche-Quesada et al. (2007), Lamonier et al. (2007), Klimova et al. (2009), Kurhinen \& Pakkanen (2000), Navarro et al. (2000), Schmal et al. (1999), Klimova et al. (1998), Regalbuto et al. (1999), Griboval et al.(1998).

Studies on the adsorption of metal ions on the surface of metal oxides are important in many fields, such as soil chemistry, geochemistry, colloid science and catalytic chemistry. In latter case, fundamental knowledge of the impregnation steps is crucial for the development of the new generation of catalysts, Kubicka \& Kaluza (2010), Pashigreva et al. (2009), Semagina \& Kiwi-Minsker (2010), Bourikas et al. (2006), Chianelli et al. (2009), Komiyama (1985), Vissenberg et al. (2000), van Veen et al. (1990), Lutra \& Cheng (1987), Wang \& Hall (1982), Hachiya et al. (1984), Gajardo et al. (1980), Giordano et al. (1975). Thus, in recent decades several adsorption models have been proposed to explain the equilibrium of adsorption of several metal cations and anions from liquid solutions. Most equations, that express the adsorption isotherms in an analytical way, have been worked out for gases, i.e. Langmuir, Freundlich and BET isotherms; however, adsorption from solutions is much more complex. This complexity is reflected in the shape of the adsorption curve, Pashigreva et al. (2009), Roukoss et al. (2009), Bourikas et al. (1998, 1996, 2006), Baumgarten \& KirchhausenDusing (1997), Pizzio et al. (1996), van Veen et al. (1987), Siri et al. (1985), Tewari et al. (1975). Study of the genesis of the equilibrium isotherms should lead to deeper insight into the nature of the processes responsible for the initial catalyst structure. All this information can be used to understand and to model catalytic phenomena.
Within this context, the present work was undertaken to determine the equilibrium parameters of $\mathrm{Mo}(\mathrm{VI})$ and $\mathrm{Co}$ (II) ion adsorption on alumina with different precursors and, simultaneously, to explore their effects in the adsorption process. As a further goal, the adsorption of $\mathrm{Co}(\mathrm{II})$ and $\mathrm{Pt}(\mathrm{IV})$ ions onto molybdenum oxide-loaded alumina was attempted.

\section{Experimental Procedure}

\subsection{Catalyst Preparation}

Three $\gamma-\mathrm{Al}_{2} \mathrm{O}_{3}$ supports from Akzo (BET area of $189 \mathrm{~m}^{2} / \mathrm{g}$; mean pore diameter determined by the BJH method of $7.64 \mathrm{~nm}$, and pore volume of 0.51 $\mathrm{cm}^{3} / \mathrm{g}$ ), Rhone-Poulenc (BET area of $196 \mathrm{~m}^{2} / \mathrm{g}$; mean pore diameter of $8.84 \mathrm{~nm}$, and pore volume of $0.50 \mathrm{~cm}^{3} / \mathrm{g}$ ), and Procatalyse (BET area of 228 $\mathrm{m}^{2} / \mathrm{g}$; mean pore diameter of $8.87 \mathrm{~nm}$ and pore volume of $0.50 \mathrm{~cm}^{3} / \mathrm{g}$ ) were used.

Molybdena-alumina catalysts used like supports for adsorption tests were prepared by impregnation of $\gamma-\mathrm{Al}_{2} \mathrm{O}_{3}$ supports with aqueous solutions of ammonium heptamolybdate (AHM, Merck), whose concentration was selected in order to obtain surface concentrations close to the theoretical monolayer of $\mathrm{MoO}_{3}$ on the $\gamma$-alumina. The preparation conditions have been reported in a previous work, Machuca et al. (2001). Here, the samples are labeled as $\mathrm{MoO}_{3} / \gamma-\mathrm{Al}_{2} \mathrm{O}_{3}$ (AK), $\mathrm{MoO}_{3} / \gamma-\mathrm{Al}_{2} \mathrm{O}_{3}$ (RO) and $\mathrm{MoO}_{3} / \gamma-\mathrm{Al}_{2} \mathrm{O}_{3}$ (PR), where AK, RO and PR refer to the Akzo, Rhodia and Procatalyse supports, respectively.

\subsection{Determination of Equilibrium Adsorption Isotherms}

The equilibrium adsorption data were obtained from the liquid solid adsorption processes. The isotherms were obtained following a typical procedure, reported previously, Machuca et al. (2001). Aqueous molybdenum, cobalt and platinum solutions were prepared from ammonium heptamolybdate (AHM, Merck), sodium molybdate dihydrate (SoMo, Merck), cobalt (II), nitrate hexahydrate (CoNi, Sigma), cobalt (II) chloride hexahydrate ( $\mathrm{CoCl}$, Aldrich), 
cobalt (II) acetate tetrahydrate (CoAc, Aldrich) and hexachloroplatinic acid (Sigma); deionized water (Milli Q quality, $18.2 \mu \Omega$ ) was used in all cases.

\subsection{Catalyst Characterization}

The metal content of the calcined samples was determined using a Perkin Elmer Optima 3300 DV inductively coupled plasma optical emission spectrometer (ICP-OES). The texture (area, mean pore diameter and pore volume) of the supports and calcined catalysts was determined from the nitrogen adsorption isotherms using a Micromeritics Digisorb 2600 automatic apparatus. DRS and UV-Vis spectra of the catalyst samples and the precursors (solid and aqueous solutions) were collected on a Shimadzu UV-2100 spectrophotometer, in the $190900 \mathrm{~nm}$ range, using $\mathrm{BaSO}_{4}$, alumina or water as references, respectively.

\section{Results and Discussion}

It is generally accepted that two kinds of coordination structures of surface molybdate species (tetrahedral and octahedral) exist on the $\gamma$ $\mathrm{Al}_{2} \mathrm{O}_{3}$ surface. Tetrahedral molybdenum oxide species are related to the isolated species, whereas octahedral molybdate species are polymerized structures. Despite this current consensus, the genesis and development of molybdate surface during preparation steps is still controversial, even though they have been studied in depth, Bejenaru et al. (2009), Baldovino-Medrano et al. (2009), De Lacaillerie \& Gan (2007), Frizi et al. (2008), Bergwerff et al. (2008), Chianelli et al. (2009), Klimova et al. (2009), Lutra \& Chebg (1987), Mestl \& Srinivasan (1998), de Wilmar et al. (1998). From all the works carried out to date, several scenarios emerge. Firstly, Jeziorowski and Knözinger, Mestl \& Srinivasan (1998), proposed that $\mathrm{MoO}_{4}^{-2}$ ions are developed on the alumina surface irrespective of the impregnating solution $\mathrm{pH}$, although these species become polymerized during the calcination step, thus leading to octahedral structures. The second model was advanced by Wang and Hall; Wang \& Hall (1982), Mestl \& Srinivasan (1998), who pointed out that the adsorbed molybdate species depend on the impregnation solution $\mathrm{pH}$ : at high $\mathrm{pH}$, only tetrahedral molybdate ions are adsorbed onto the $\gamma-\mathrm{Al}_{2} \mathrm{O}_{3}$ surface, whereas at low $\mathrm{pH}$ the adsorption of polymolybdate ions (octahedral symmetry) dominates. Then, Xiong et al. (2000) reported that the coordination structures of the surface species are essentially influenced by the net $\mathrm{pH}$ value at the surface region of the support. Rencently, Bergwerff et al. (2008), reported that there are interactions between Co Mo ions in solutions and that this can have consequences for the preparation of supported CoMo HDS catalysts. In this case, the CoMo-complexes can be formed on the catalyst surface, where the $\mathrm{Co}(\mathrm{II})$ is bound to the outside the molybdate-ions.

\section{$3.1 \mathrm{pH}$ and adsorption behavior}

\subsubsection{Mo/ $\gamma-\mathrm{Al}_{2} \mathrm{O}_{3}$ systems}

Spectroscopic studies (UV-Vis) were performed to determine the ionic species present in solution; in parallel, the DRS UV-Vis spectra of the impregnated solids were recorded. Although the use of aqueous molybdate solutions is debatable, Bergwerff et al. (2008), Duan et al. (2007), Weber (1995), Fournier et al. (1989), due to the complex chemistry of molybdate ions in solution, the approach undertaken here is reasonable.

Although the tetrahedral $\mathrm{MoO}_{4}{ }^{2-}$ ion can be protonated in solution and its coordination sphere is solvated by $\mathrm{H}_{2} \mathrm{O}$, leading to an increase in the Mo coordination number, Fournier et al. (1989), this process will lead to an overlapping in the absorption UV-Vis region with the octahedral molybdenum species. Along the preparation of $\mathrm{MoO}_{3}$ /alumina samples, carried out by impregnation of alumina with aqueous solutions of $\mathrm{Na}_{2} \mathrm{MoO}_{4}$, Xiong et al. (2000) found that in the wet, dry and calcined states all the samples exhibited Mo species that were tetrahedrally coordinated by oxygen ions, even after calcination. In the present work, the UV-Vis spectra of Mo, Co and Pt solutions were used to identify the nature of molybdenum oxo-species in solution. On the other hand, the comparison of the DR spectra of the salt precursors and the impregnated samples, allows one to distinguish among the molybdenum species present on the support surface. Apart from this, other techniques 
have been used to unveil the symmetry and nature of the adsorbed species (i.e. optical band-gap energy, Eg and Gaussian analysis) from DRS/UVVis spectra, Weber (1995), Fournier et al. (1989).

Along the adsorption of metal ions on the alumina surface, the $\mathrm{pH}$ values of the impregnating solution were seen to change. Table 1 compiles both the initial and final $\mathrm{pH}$ ranges for all the systems under study. From these data, it is clear that the $\mathrm{pH}$ of the solution changes not only along the impregnation process but also with the initial concentration of the impregnating solution. Although the type of anionic species present in molybdate solutions depends on their $\mathrm{pH}$ value, Bergwerff et al. (2008), Regalbuto et al. (1999), Lutra \& Cheng (1987), Mestl \& Srinivasan 1998), under the nearly acid solutions employed in the present work most of the molybdenum species in solution were polymeric ions (octahedral symmetry) because the ionic equilibrium was shift to the left-hand side:

$\mathrm{Mo}_{7} \mathrm{O}_{24}{ }^{6-}+4 \mathrm{H}_{2} \mathrm{O} \Leftrightarrow 7 \mathrm{MoO}_{4}{ }^{2}-+8 \mathrm{H}+$

Therefore, the adsorption of molybdate ions $\left(\mathrm{Mo}_{7} \mathrm{O}_{24}\right)^{6-}$ shifts the $\mathrm{pH}$ to values close to point of zero charge of the support at the end of impregnation. Figure 1 shows the $\mathrm{pH}$ change at adsorption equilibrium. In all cases, the final $\mathrm{pH}$ values are higher than the initial ones. This type of behavior is similar to that observed by Spanos et al. $(2006,1990)$ for a similar system. However, the comparison of the final $\mathrm{pH}$ values for the adsorption of molybdate ions on alumina revealed some differences, although they were considered no significant.

Contrariwise, most solution oxo-molybdenum species present during the impregnation with SoMo salt were monomeric $\left(\mathrm{MoO}_{4}^{-2}\right)$ species in tetrahedral symmetry. In this case, the change in $\mathrm{pH}$ values became smaller than those originated upon AHM impregnation (see Table 1). This observation can be related to the extent of adsorption, which in turn was substantially lower than that observed for AHM solutions. This can be explained as being due to a weak interaction between the monomeric ions and the adsorption sites. These results are in agreement with the reported by several authors, Iannibello \& Mitchell (1979), Weigold (1983), Butz et al. (1989), Plyuto et al. (1997) and Jiang et al. (2008).

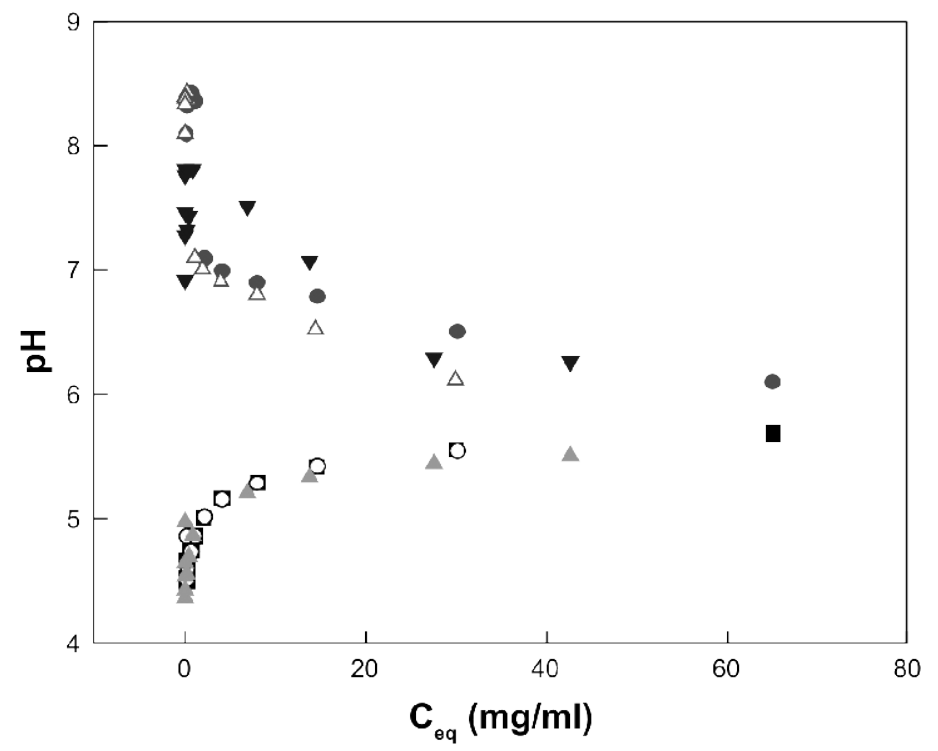

Figure 1. pH vs. Ceq profiles. Adsorption of AHM solution over alumina: (ロ) final

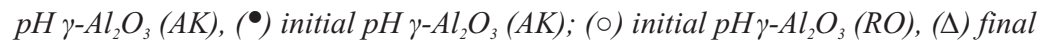

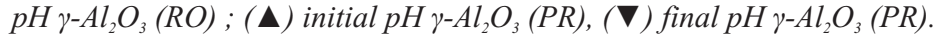


Ingeniería y Competitividad, Volumen 12, No. 1, p. 73 - 93 (2010)

Table 1. $\mathrm{pH}$ values for metal ion adsorption on $\gamma-\mathrm{Al}_{2} \mathrm{O}_{3}$ or $\mathrm{MoO}_{3} / \gamma-\mathrm{Al}_{2} \mathrm{O}_{3}$

\begin{tabular}{|c|c|c|c|c|c|}
\hline System $^{a}$ & Alumina & Initial Range $\mathrm{pH}$ & Final Range $\mathrm{pH}$ & $\begin{array}{c}\mathrm{pH}_{\mathrm{ZPC}} \\
\text { Support }\end{array}$ & $\begin{array}{l}\text { Initial content. range } \\
\qquad(\mathrm{mg} / \mathrm{mL})^{\mathrm{b}}\end{array}$ \\
\hline $\mathrm{AHM} / \gamma-\mathrm{Al}_{2} \mathrm{O}_{3}$ & $\mathrm{AK}$ & $4.87-5.70$ & $6.40-7.72$ & 7.56 & $0.013-65.00$ \\
\hline $\mathrm{AHM} / \gamma-\mathrm{Al}_{2} \mathrm{O}_{3}$ & RO & $4.87-5.70$ & $6.11-8.10$ & 7.84 & $0.013-65.00$ \\
\hline $\mathrm{AHM} / \gamma-\mathrm{Al}_{2} \mathrm{O}_{3}$ & PR & $4.49-4.96$ & $6.26-7.28$ & 7.72 & $0.013-42.50$ \\
\hline $\mathrm{SoMo} / \gamma-\mathrm{Al}_{2} \mathrm{O}_{3}$ & AK & $7.14-7.32$ & $7.36-8.72$ & 7.56 & $0.013-29.98$ \\
\hline $\mathrm{SoMo} / \gamma-\mathrm{Al}_{2} \mathrm{O}_{3}$ & $\mathrm{RO}$ & $7.14-7.32$ & $8.42-8.24$ & 7.84 & $0.013-29.98$ \\
\hline $\mathrm{SoMo} / \gamma-\mathrm{Al}_{2} \mathrm{O}_{3}$ & PR & $7.06-7.14$ & $7.50-8.62$ & 7.72 & $0.055-26.00$ \\
\hline $\mathrm{CoNi} / \gamma-\mathrm{Al}_{2} \mathrm{O}_{3}$ & $\mathrm{AK}$ & $7.04-6.57$ & $6.96-5-.65$ & 7.56 & $0.005-6.200$ \\
\hline $\mathrm{CoNi} / \gamma-\mathrm{Al}_{2} \mathrm{O}_{3}$ & RO & $7.04-6.57$ & $7.60-4.77$ & 7.84 & $0.005-6.200$ \\
\hline $\mathrm{CoNi} / \gamma-\mathrm{Al}_{2} \mathrm{O}_{3}$ & PR & $6.37-5.08$ & $7.61-5.54$ & 7.72 & $0.021-11.07$ \\
\hline $\mathrm{CoCl} / \gamma-\mathrm{Al}_{2} \mathrm{O}_{3}$ & $\mathrm{AK}$ & $7.50-4.55$ & $5.66-5.79$ & 7.56 & $0.006-6.200$ \\
\hline $\mathrm{CoCl} / \gamma-\mathrm{Al}_{2} \mathrm{O}_{3}$ & RO & $7.50-4.55$ & $7.54-5.90$ & 7.84 & $0.006-6.200$ \\
\hline $\mathrm{CoCl} / \gamma-\mathrm{Al}_{2} \mathrm{O}_{3}$ & PR & $7.02-7.50$ & $6.05-5.55$ & 7.72 & $0.0016-5.80$ \\
\hline $\mathrm{CoAc} / \gamma-\mathrm{Al}_{2} \mathrm{O}_{3}$ & $\mathrm{AK}$ & $8.08-7.27$ & $7.04-5.80$ & 7.56 & $0.008-6.300$ \\
\hline $\mathrm{CoAc} / \gamma-\mathrm{Al}_{2} \mathrm{O}_{3}$ & RO & $8.08-7.27$ & $7.38-5.69$ & 7.84 & $0.008-6.300$ \\
\hline $\mathrm{CoAc} / \gamma-\mathrm{Al}_{2} \mathrm{O}_{3}$ & PR & $7.02-7.50$ & $7.15-5.73$ & 7.72 & $0.0016-5.80$ \\
\hline $\mathrm{Co} / \mathrm{MoO}_{3}-\gamma-\mathrm{Al}_{2} \mathrm{O}_{3}$ & $\mathrm{AK}$ & $6.71-6.57$ & $3.30-3.68$ & 3.62 & $0.750-13.00$ \\
\hline $\mathrm{Co} / \mathrm{MoO}_{3}-\gamma-\mathrm{Al}_{2} \mathrm{O}_{3}$ & $\mathrm{RO}$ & $6.71-6.57$ & $3.87-3.80$ & 3.80 & $0.750-13.00$ \\
\hline $\mathrm{Pt} / \mathrm{MoO}_{3}-\gamma-\mathrm{Al}_{2} \mathrm{O}_{3}$ & $\mathrm{AK}$ & $2.20-1.57$ & $3.65-3.60$ & 3.62 & $0.500-3.300$ \\
\hline $\mathrm{Pt} / \mathrm{MoO}_{3}-\gamma-\mathrm{Al}_{2} \mathrm{O}_{3}$ & $\mathrm{RO}$ & $2.20-1.57$ & $3.73-3.82$ & 3.80 & $0.500-3.300$ \\
\hline $\mathrm{Pt}-(\mathrm{Co}) / \mathrm{MoO}_{3}-\gamma \mathrm{Al}_{2} \mathrm{O}_{3}$ & $\mathrm{AK}$ & $2.67-4.04$ & $3.39-3.86$ & 3.62 & $0.030-0.120$ \\
\hline $\mathrm{Co}-(\mathrm{Pt}) / \mathrm{MoO}_{3} \gamma \mathrm{Al}_{2} \mathrm{O}_{3}$ & $\mathrm{AK}$ & $2.67-4.04$ & $3.39-4.86$ & 3.62 & $0.270-8.500$ \\
\hline
\end{tabular}

a Solution with support; ${ }^{\mathrm{b}}$ Amount of metal ion in solution; ${ }^{\mathrm{c}}$ Solution with two ions

Since the alumina sites involved in the impregnation with AHM and SoMo salts was virtually the same, the surface had greater affinity for the polymeric species. This behavior could be related with the species on surface of supports, this species could change with the adsorption conditions, especially the $\mathrm{pH}$. These results are in agreement with the findings of Luthra \& Cheng (1987), Hall \& Wang (1982) and Al-Dalama et al. (2005).

The electronic spectra of AHM and SoMo solutions are shown in Figs. 2 and 3, respectively.
The positions of the absorption bands are also compiled in Table 2. With increasing molybdenum concentrations, the main band shifted toward a higher wavelength. However, SoMo solutions exhibited a shoulder at $234 \mathrm{~nm}$, whose position did not change with increasing Mo concentrations. This shoulder was also observed in AHM solutions, although it shifted slightly with the Mo concentration. For SoMo solutions, the shoulder was overshadowed by an intense band at around $250 \mathrm{~nm}$, and disappeared at Mo concentrations over $250 \mathrm{ppm}$. 


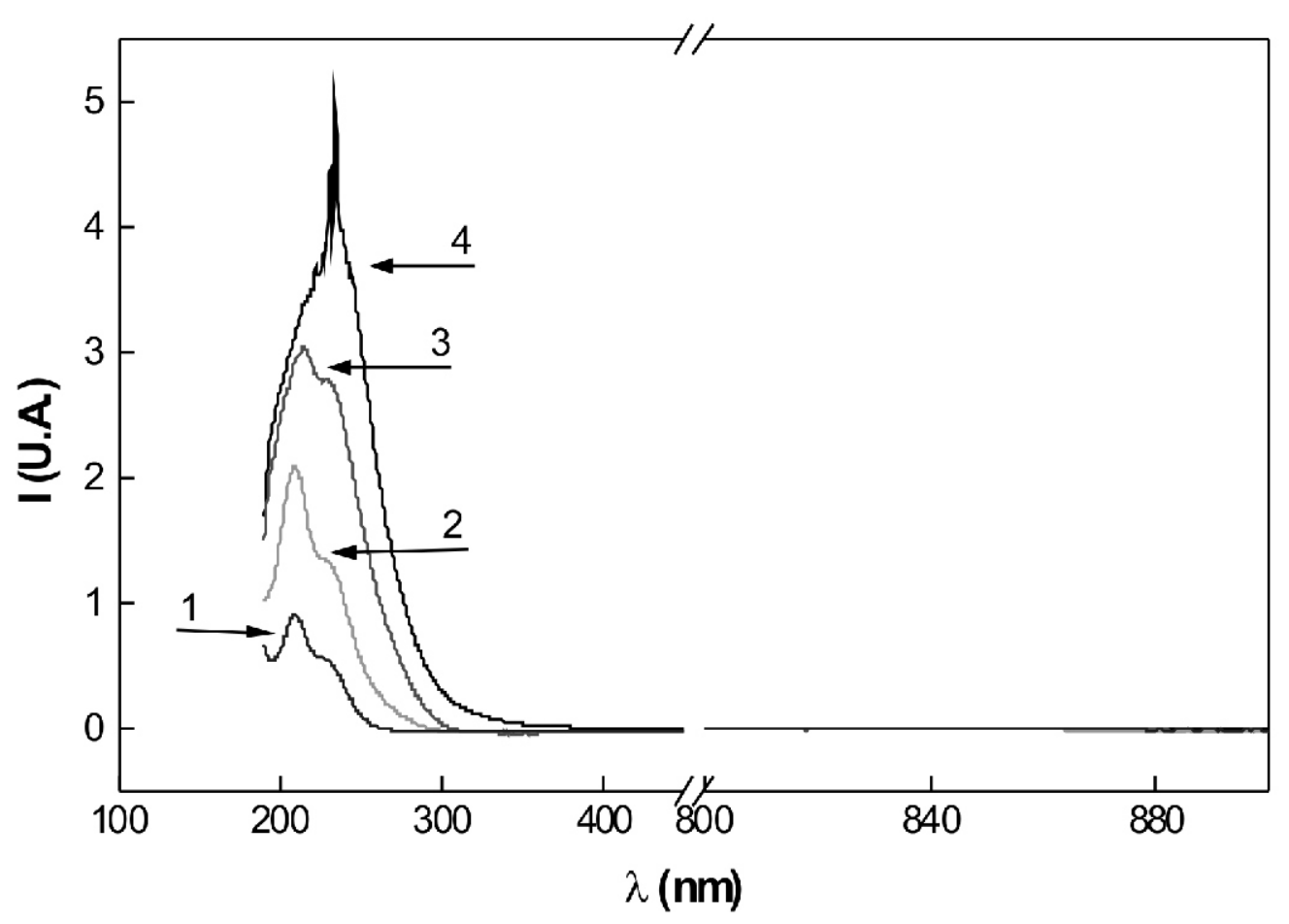

Figure 2. Uv-Vis spectra of AHM solutions. (1) 13 ppm; (2) 30 ppm; (3) 60 ppm; (4) 120 ppm

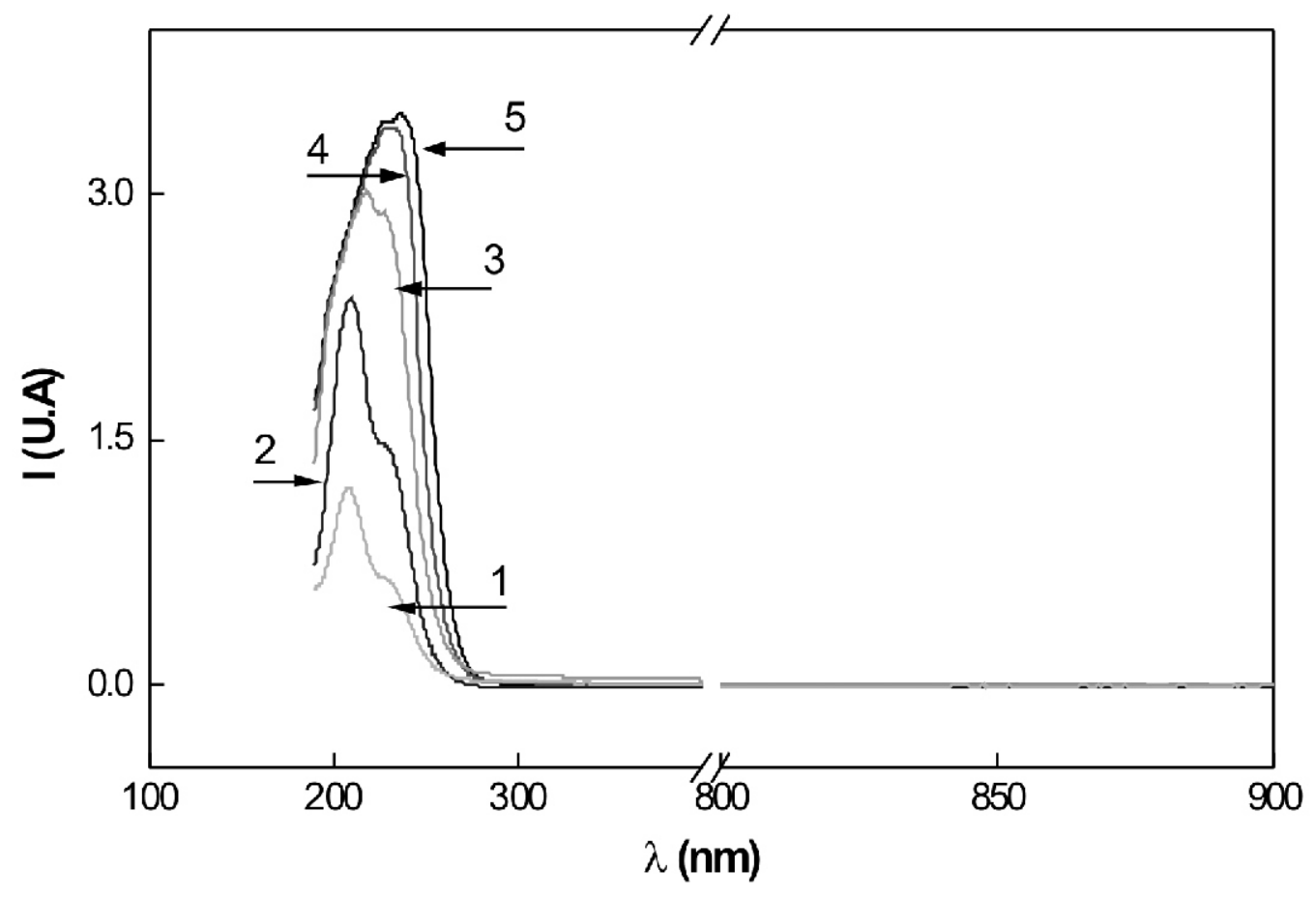

Figure 3. Uv-Vis spectra of SoMo Solutions. (1) $13 \mathrm{ppm}$; (2) $33 \mathrm{ppm}$; (3) $65 \mathrm{ppm}$; (4) $130 \mathrm{ppm}$; (5) $250 \mathrm{ppm}$ 
Ingeniería y Competitividad, Volumen 12, No. 1, p. 73 - 93 (2010)

Table 2. Principal bands in UV-Vis spectra and $\mathrm{pH}$ for AHM and SoMo Solutions

\begin{tabular}{|c|c|c|c|c|c|}
\hline $\begin{array}{l}\text { Solution } \\
\text { System }\end{array}$ & $\begin{array}{c}\text { Dominant molybdate } \\
\text { species }\end{array}$ & Initial $\mathrm{pH}$ & $\begin{array}{l}\text { Mo Concentration } \\
(\mathrm{ppm})\end{array}$ & $\begin{array}{c}\text { Mean Band Peak } \\
(\mathrm{nm})\end{array}$ & Shoulder (nm) \\
\hline & \multirow{4}{*}{ Polymeric } & 4.51 & 120 & $231.0-234.5^{\mathrm{a}}$ & \\
\hline \multirow{3}{*}{ AHM } & & 4.53 & 60 & 214.0 & 235.5 \\
\hline & & 4.67 & 30 & 209.5 & 234.5 \\
\hline & & 4.87 & 13 & 209.0 & 234.0 \\
\hline \multirow{5}{*}{ SoMo } & \multirow{5}{*}{ Monomeric } & 7.17 & 250 & $237.0^{\mathrm{b}}$ & \\
\hline & & 7.31 & 130 & $233.0^{\mathrm{b}}$ & \\
\hline & & 7.10 & 65 & 218.0 & 234.0 \\
\hline & & 7.24 & 33 & 209.5 & 234.0 \\
\hline & & 7.14 & 13 & 208.5 & 234.0 \\
\hline
\end{tabular}

a Distortion spectra; b One band

The energy of electronic transitions depends strongly on the ligand field symmetry surrounding the molybdenum center. For oxo-ligands, a more energetic transition is expected for a tetrahedral $\mathrm{Mo}(\mathrm{VI})$ than for octahedral Mo(VI), Fournier et al (1989). The comparison of the electronic spectra obtained for SoMo and AHM solutions revealed a greater difference in the shift of the main band of the former solutions when the Mo concentration was increased. The difference was found at $5 \mathrm{~nm}$ $(0.138 \mathrm{eV})$ and $9.5 \mathrm{~nm}(0.259 \mathrm{eV})$, respectively, although a greater difference $(28.5 \mathrm{~nm}-0.715 \mathrm{eV})$ can be seen if the main band at $250 \mathrm{ppm}$ is taken into consideration. Nevertheless, the differences between the tetrahedral and octahedral species in aqueous media were quite small. Thus, an overlapping of the bands in the electronic spectra of the tetrahedral and octahedral species is expected to occur. For both solutions the largest difference observed was $4 \mathrm{~nm}(0.106 \mathrm{eV})$.

Figure 4 shows the DR spectra for $\mathrm{Mo} / \mathrm{Al}_{2} \mathrm{O}_{3}$ samples prepared from AHM solutions in the oxidized $\left(\mathrm{MoO}_{3}\right)$ and impregnated (AHM ion) states. The spectrum of the $\mathrm{MoO}_{3} / \mathrm{Al}_{2} \mathrm{O}_{3}$ exhibits a strong adsorption, with a maximum at $247.5 \mathrm{~nm}$, similar to that of the dry impregnates exhibiting bands at 244.5 and $243 \mathrm{~nm}$. The shape of the spectra was similar for all the samples. The absorption band has the typical shape of Mo(VI) species, Lutra \& Cheng (1987), Xiong et al. (2000), Fournier et al. (1989). Since the Mo(VI) ion has a $\mathrm{d} 0$ electronic configuration, the only absorption band that is able to arise in the UV-Vis range of the electronic spectra comes from ligandmetal charge transfer. This band type is usually observed between 200 and $400 \mathrm{~nm}$. However, since the alumina itself exhibits a broad band at 200-350 nm, the resulting spectra of the $\mathrm{MoO}_{3} / \mathrm{Al}_{2} \mathrm{O}_{3}$ systems could be considered as the overlap of the adsorption bands at 225, 275 and $300 \mathrm{~nm}$. The resulting broad band suggests that both molybdate species were developed in the wet state on the alumina surface. After drying and calcination, the band is still broad, suggesting the formation of some surface polymerized molybdate species. This inference is consistent with the observations of Fournier et al. (1989) and Ramirez et al.(1999).

The DR spectra for AHM and SoMo salt precursors only exhibit the characteristic wavelength bands for octahedral and tetrahedral species respectively, van Veen et al. $(1987,1990)$, Lutra \& Cheng (1987), Hachiya et al. (1984), Gajardo et al. (1980), Fournier et al. (1989). There were larger differences in the intensity and wavelength positions for the octahedral and tetrahedral symmetries, due to different interactions between the Mo atoms and their surroundings, this it is related with the structure of $\mathrm{MoO}_{3}$ and its crystal faces obtained by molecular modeling, Gesarai et al (1997). 


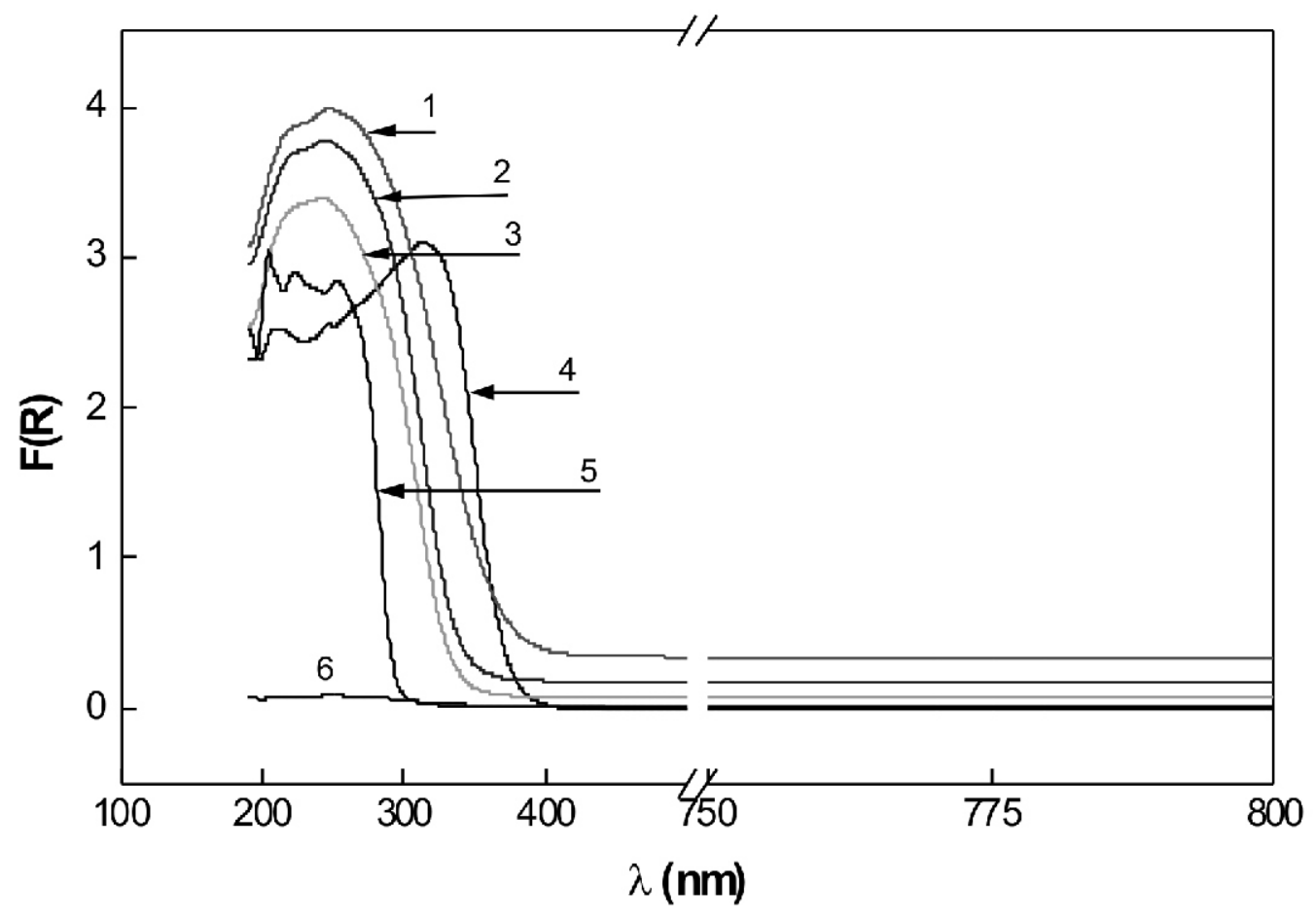

Figure 4. DRS-Uv-Vis spectra of Mo/alumina samples: (1) $\mathrm{MoO}_{3} / \gamma-\mathrm{Al}_{2} \mathrm{O}_{3}$; (2) $\mathrm{AHM} / \gamma-\mathrm{Al}_{2} \mathrm{O}_{3}$, rotary evaporator dried; (3) $\mathrm{AHM} / \gamma-\mathrm{Al}_{2} \mathrm{O}_{3}$, dried naturally; (4) AHM salt; (5) SoMo salt; (6.), $\Gamma$-Al2O3 (AK) support.

The analysis of the reflectance spectra using model compounds confirmed that both type species (octahedral and tetrahedral) were present in the impregnates. Although most octahedral species were in solution, a small proportion of monomeric $\mathrm{MoO}_{4}^{-2}$ species always remained in equilibrium with the heptamer (Eq. 1), which may also lead to adsorption on the surface as minor species, Jiang et al. (2008) and Weigold (1983). Finally, we found that the hydration degree and the type of drying ( $\mathrm{RD}$, rotary dry; $\mathrm{ND}$, natural dry) did not change the DR spectra, and exerted a negligible effect on the absorption bands of $\mathrm{AHM} / \mathrm{Al}_{2} \mathrm{O}_{3}$ sample. Thus, as already reported by Fournier et al. (1989), the structure of the adsorbed species should not change.

\subsubsection{Co and/or Pt on $\gamma-\mathrm{Al}_{2} \mathrm{O}_{3}$ or $\mathrm{MoO}_{3} / \gamma-$ $\mathrm{Al}_{2} \mathrm{O}_{3}$ systems}

A similar behavior was observed for the adsorption of cobalt and platinum ions on the $\mathrm{MoO}_{3} / \gamma-\mathrm{Al}_{2} \mathrm{O}_{3}$ surface. Under the experimental conditions used, most ionic species in solution were Pt (IV) and Co(II), in agreement with the work of Regalbuto et al. (1999) for Pt, and of Tamura et al. (1997) and Bergwerff et al. (2008) for Co ions. Also, the UV-Vis spectra for cobalt solutions (not shown here) were essentially the same as those reported by Tomisic \& Simeon (1999). However, the initial $\mathrm{pH}$ of the impregnating $\mathrm{H}_{2} \mathrm{PtCl}_{6}$ solutions was lower than that reported by Ruckenstein \& Karpe (1989) for $\mathrm{Pt}$ ions. The general equations for complete dissociation of the salts in aqueous medium are:

$\mathrm{H}_{2} \mathrm{PtCl}_{6} \Leftrightarrow 2 \mathrm{H}^{+}+\mathrm{PtCl}_{6}^{2-}$

$\mathrm{Co}\left(\mathrm{NO}_{3}\right)_{2} \Leftrightarrow 2 \mathrm{NO}_{3}^{-}+\mathrm{Co}^{2+}$

For ensuring the adsorption equilibrium had been reached, each point of the adsorption isotherm $(298 \mathrm{~K})$ was extended for a much longer time (24 h). As pointed out in the previous section, the adsorption of ions on the alumina surface led to significant changes in the $\mathrm{pH}$ of the impregnating solution. The results offered in Table 1 indicate that the initial solution $\mathrm{pH}$ for most solutions 
shifted to values close to the point of zero charge of the support $\left(\gamma-\mathrm{Al}_{2} \mathrm{O}_{3}\right.$ or $\left.\mathrm{MoO}_{3} / \gamma-\mathrm{Al}_{2} \mathrm{O}_{3}\right)$ at the end of impregnation. For a given support, the final $\mathrm{pH}$ values were in general higher than the initial $\mathrm{pH}$ for the impregnation of $\mathrm{Pt}$ on $\mathrm{MoO}_{3} / \gamma-\mathrm{Al}_{2} \mathrm{O}_{3}$ and $\mathrm{Pt}-\mathrm{Co}$ on $\mathrm{MoO}_{3} / \gamma-\mathrm{Al}_{2} \mathrm{O}_{3}$, while $\mathrm{pH}$ was lower for the impregnation of $\mathrm{Co}$ on $\mathrm{MoO}_{3} / \gamma-\mathrm{Al}_{2} \mathrm{O}_{3}$. This observation is consistent with the close proximity of the final $\mathrm{pH}$ solution and the point of zero charge of $\left(\mathrm{pH}_{\mathrm{ZPC}}\right)$ of the molybdena support at the adsorption equilibrium. It should be noted that the final $\mathrm{pH}$ values of the impregnating solutions approached the $\mathrm{pH}_{\mathrm{ZPC}}$ of the solid $\left(\mathrm{MoO}_{3} / \gamma-\mathrm{Al}_{2} \mathrm{O}_{3}\right.$ and $\left.\gamma-\mathrm{Al}_{2} \mathrm{O}_{3}\right)$. These results are in complete agreement with the $\mathrm{pH}_{\mathrm{ZPC}}$ values reported by Kohler et al. (1992) for $\mathrm{MoO}_{3} / \mathrm{Al}_{2} \mathrm{O}_{3}$ system and with those of Tawei et al. (1997) for $\gamma-\mathrm{Al}_{2} \mathrm{O}_{3}$. A final remark is that for the concentration limit of $\mathrm{Co}(\mathrm{II})$ ions, the $\mathrm{pH}$ values are lower than expected.

\subsection{Adsorption isotherms}

The adsorption isotherms of molybdenum (cobalt and platinum) at a constant temperature of $298 \mathrm{~K}$, expressed as the amount of metal ion retained per gram of solid $\left(\mathrm{C}_{\mathrm{a}}\right)$ as a function of the metal ion concentration of the impregnating solution at equilibrium $\left(\mathrm{C}_{\mathrm{eq}}\right)$, were determined. The experimental isotherms for the different supports are shown in (Figs. 5-11.) The isotherms for the metal ion $/ \gamma-\mathrm{Al}_{2} \mathrm{O}_{3}$ systems belong to the L-type of the Giles classification, Giles et al. (1974). Exceptions were the isotherms obtained using CoAc and $\mathrm{CoCl}$ salt precursors and a PR alumina (Fig. 10), and also Pt (Co) on $\mathrm{MoO}_{3}$ /alumina (Fig. 11).

For the adsorption of molybdate ions, the shape of the isotherms (Figs. 5 and 6) coincides with that reported in the literature for this system, Al-Dalama et al. (2005), Bourikas et al. (1998), Pizzio et al. (1996), van Veen et al. (1987), Mulcahy et al. (1987). However, depending on the range of $\mathrm{C}_{\mathrm{eq}}$ values investigated, the shape of these isotherms may vary. Thus, more complex shapes can be found, particularly if the isotherm covers a broad range of Ceq concentrations, Vissenberg et al. (2000), Bourikas et al. (1996, 1998, 2006). Ca values increased rapidly with $\mathrm{C}_{\mathrm{eq}}$ in the range of concentrations up to ca. $15 \mathrm{mg} / \mathrm{ml}$ and $5 \mathrm{mg} / \mathrm{ml}$ for the AHM and SoMo solutions, respectively, whereas the curves flattened off at higher concentrations. An important distinction among the three $\gamma-\mathrm{Al}_{2} \mathrm{O}_{3}$ supports is that, whatever the concentration, higher amounts of Mo were retained by the $\gamma-\mathrm{Al}_{2} \mathrm{O}_{3}$ (AK) sample. Moreover, the experimental isotherms determined using the impregnating SoMo salt precursor clearly shows up the differences in the adsorption capability of the three $\gamma-\mathrm{Al}_{2} \mathrm{O}_{3}$ substrates. In this case, the sequence in adsorption capability was $\mathrm{AK} \gg \mathrm{RO} \gg \mathrm{PR}$ alumina. The adsorption capacity was highest when AHM salt was used as the impregnating solution, in which case the sequence was $\mathrm{AK}>>\mathrm{RO}>\mathrm{PR}$.

The adsorption behavior is influenced by the surface properties of the alumina (adsorption sites, IEP and/or ZPC) and the solution characteristics ( $\mathrm{pH}$ and nature of the ionic species), Lutra \& Chang (1987), Mestl \& Srinivasan (1998), Semagina \& KiwiMinsker (2009). On the basis of these characteristic properties, an explanation of the differences found between the adsorption of AHM (octahedral species) and SoMo (tetrahedral) salt precursors can be offered. The AK-type alumina must have a higher affinity for octahedral than for tetrahedral species because the AK alumina showed a higher experimental S (mg ion/g support) value. By contrast, a poor affinity of the surface for tetrahedral molybdate species was reflected in the adsorption from SoMo solutions in which only tetrahedral $\mathrm{MoO}_{4}{ }^{2-}$ species, but in no case octahedral $\mathrm{Mo}_{7} \mathrm{O}_{24}{ }^{6-}$ units, are present. The RO and PR alumina samples showed a similar kind of behavior. Upon observing the adsorption isotherms in (Figs. 5 and 6), it appears that the $\mathrm{RO}$ and $\mathrm{PR} \gamma-\mathrm{Al}_{2} \mathrm{O}_{3}$ substrates would have similar proportions of adsorption sites for the octahedral species, although still lower than for the PR counterpart. It should be stressed that specific area and porosity would have only a minor influence in the adsorption of molybdate ions.

A similar type of behavior was observed for the adsorption of $\mathrm{Co}$ (II) ions on alumina, see (Figs. 710), Bergwerff et al. (2008), Wang \& Hall (1982), Bourikas et al. (1998), Siri et al. (1985). In all cases, the PR-type alumina had a slightly higher adsorption capacity than the other aluminas. There is, however, an interesting point to be considered in (Fig. 10); although the initial concentration was the same for all the experiments, $\mathrm{C}_{\mathrm{eq}}$ values were very different at the end of the adsorption (a higher amount of $\mathrm{Co}$ (II) ions was adsorbed). Thus, PR-type alumina 


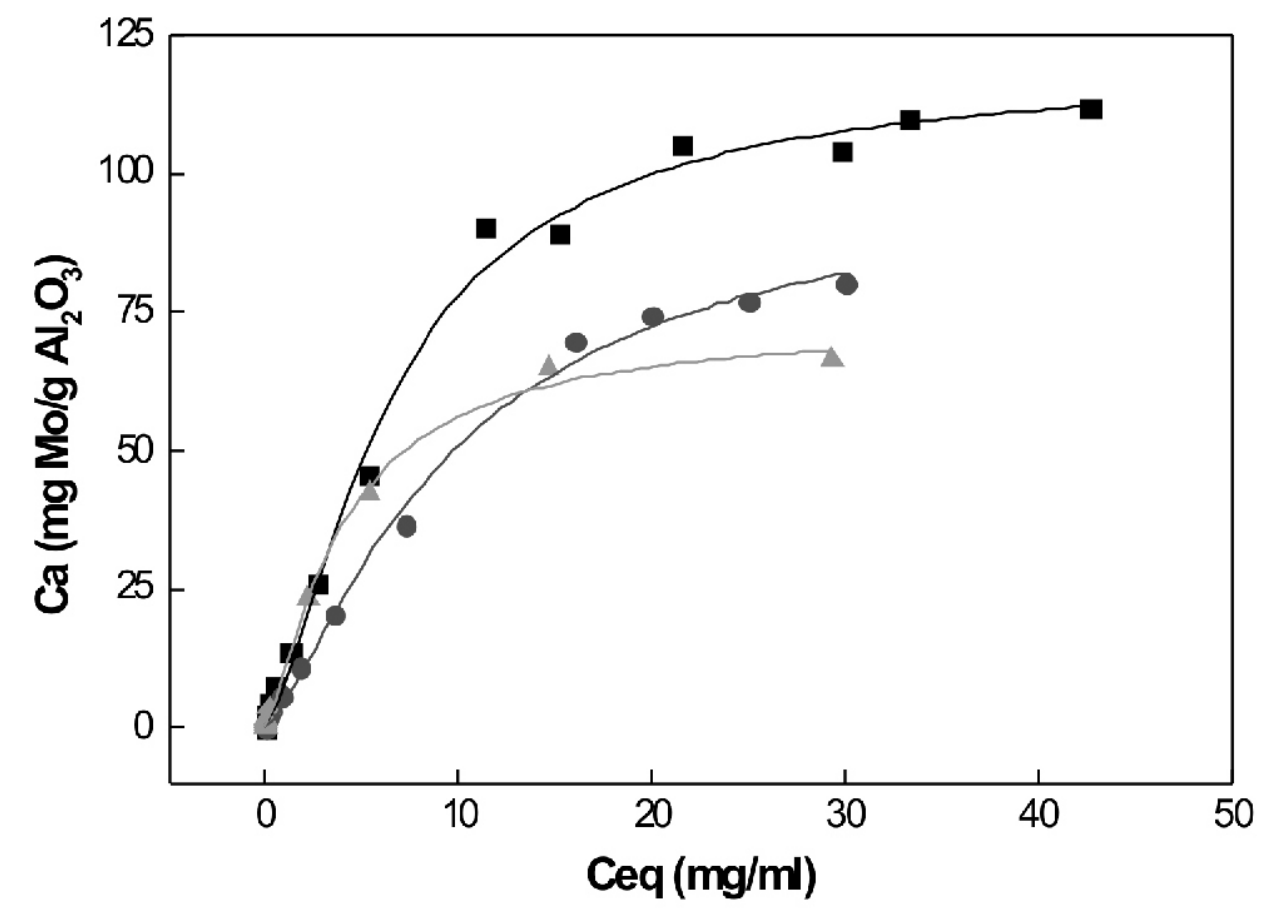

Figure 5. Room temperature adsorption isotherms of molybdenum (AHM) on alumina supports: (ロ) $\gamma$ - $\mathrm{Al}_{2} \mathrm{O}_{3}$ $(A K) ;\left(\bullet \gamma-\mathrm{Al}_{2} \mathrm{O}_{3}(\mathrm{RO}) ;(\mathbf{\Delta}) \gamma-\mathrm{Al}_{2} \mathrm{O}_{3}(\mathrm{PR})\right.$. The lines represent the fitting of the experimental adsorption data to the isotherms derived from the equilibrium parameters.

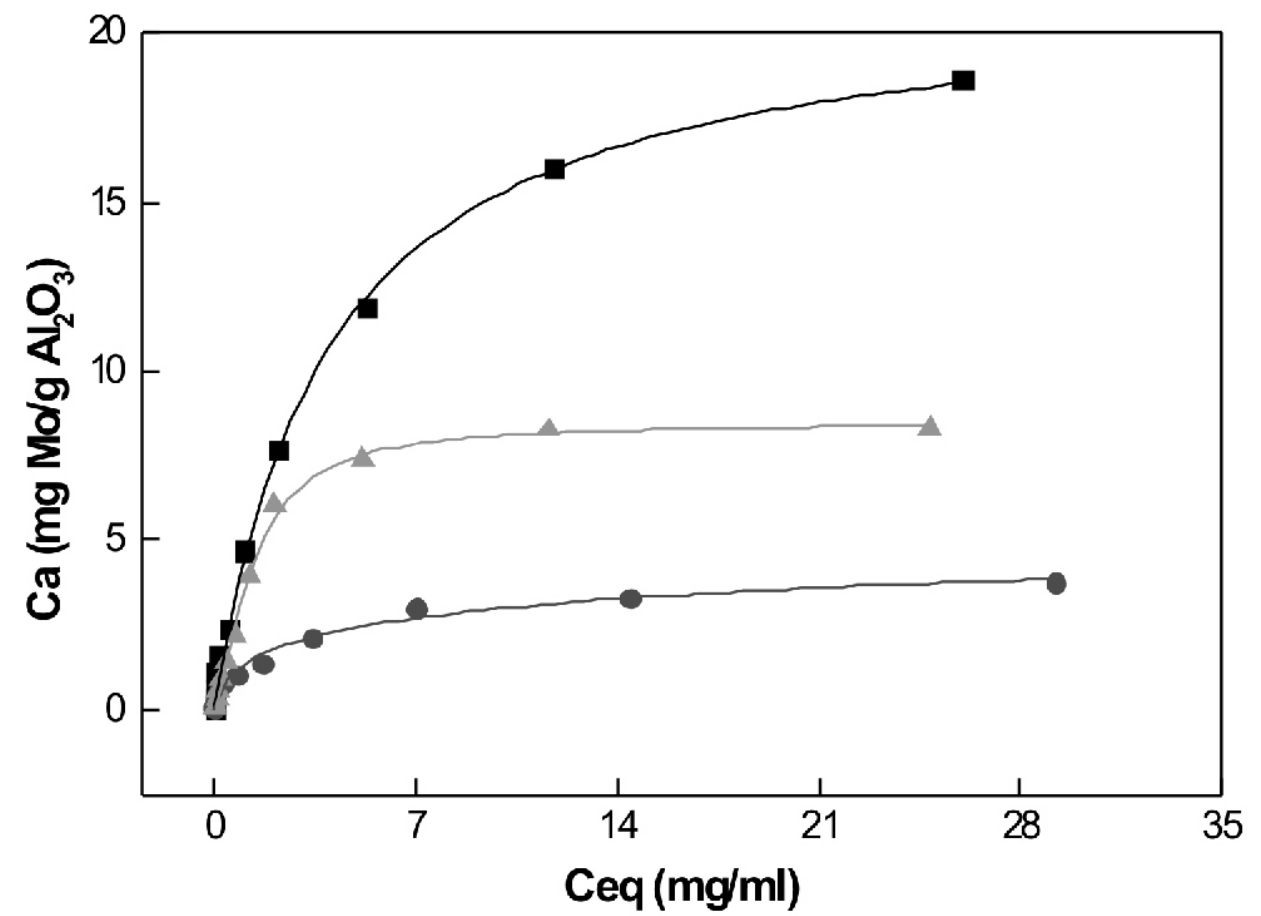

Figure 6. Room temperature adsorption isotherms of molybdenum (SoMo) on alumina supports: (曰) $\gamma-\mathrm{Al}_{2} \mathrm{O}_{3}(\mathrm{AK})$; (•) $\gamma-\mathrm{Al}_{2} \mathrm{O}_{3}(\mathrm{RO})$; ( $\left.\mathbf{\Delta}\right) \gamma-\mathrm{Al}_{2} \mathrm{O}_{3}(\mathrm{PR})$. The lines represent the fitting of the experimental adsorption data to the isotherms derived from the equilibrium parameters. 


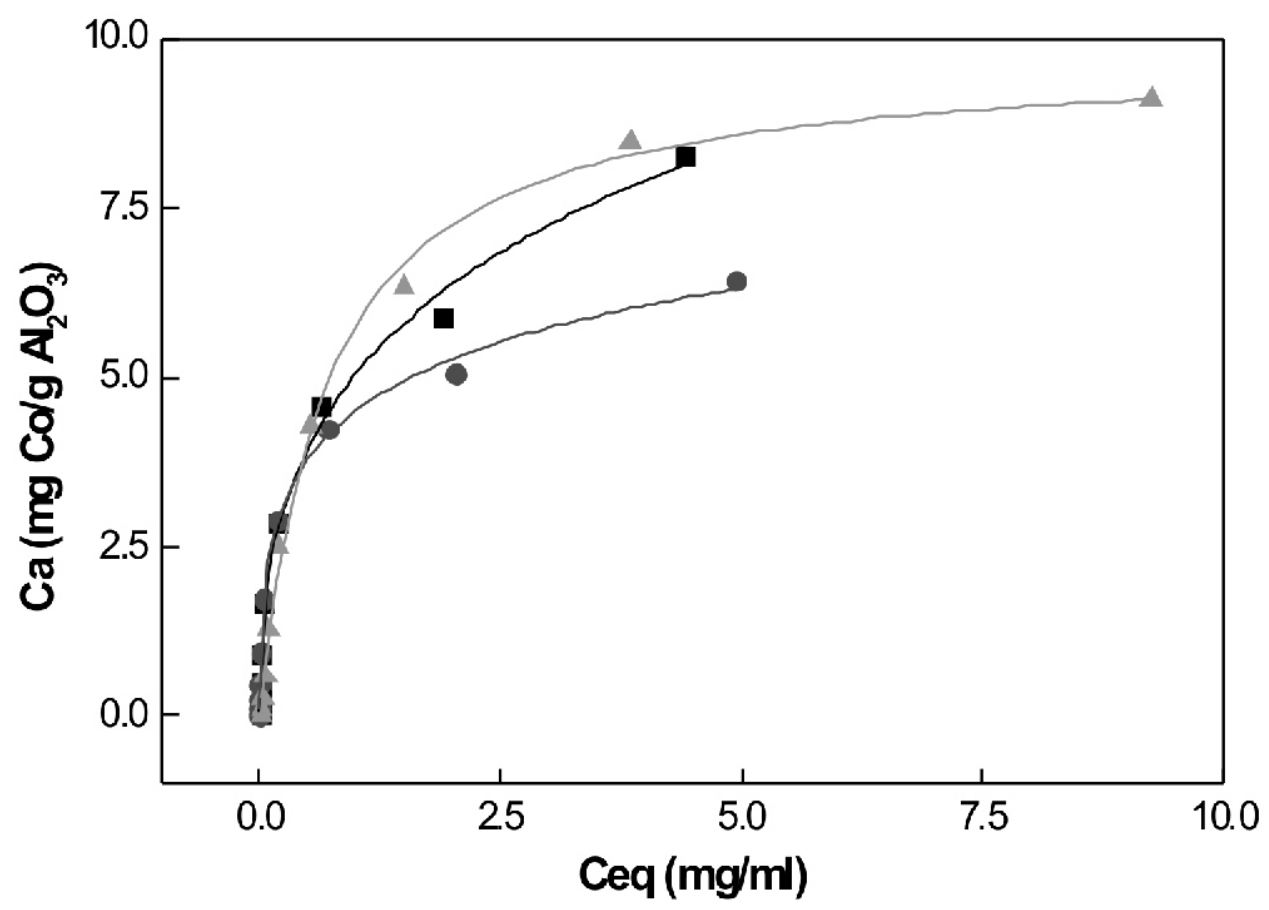

Figure 7. Room temperature adsorption isotherms of cobalt (CoNi) on alumina supports: (ロ) $\gamma$ - $A l_{2} O_{3}(A K) ;(\bullet) \gamma$ $\mathrm{Al}_{2} \mathrm{O}_{3}(\mathrm{RO})$; ( $\left.\mathbf{\Delta}\right) \gamma-\mathrm{Al}_{2} \mathrm{O}_{3}(\mathrm{PR})$. The lines represent the fitting of the experimental adsorption data to the isotherms derived from the equilibrium parameters.

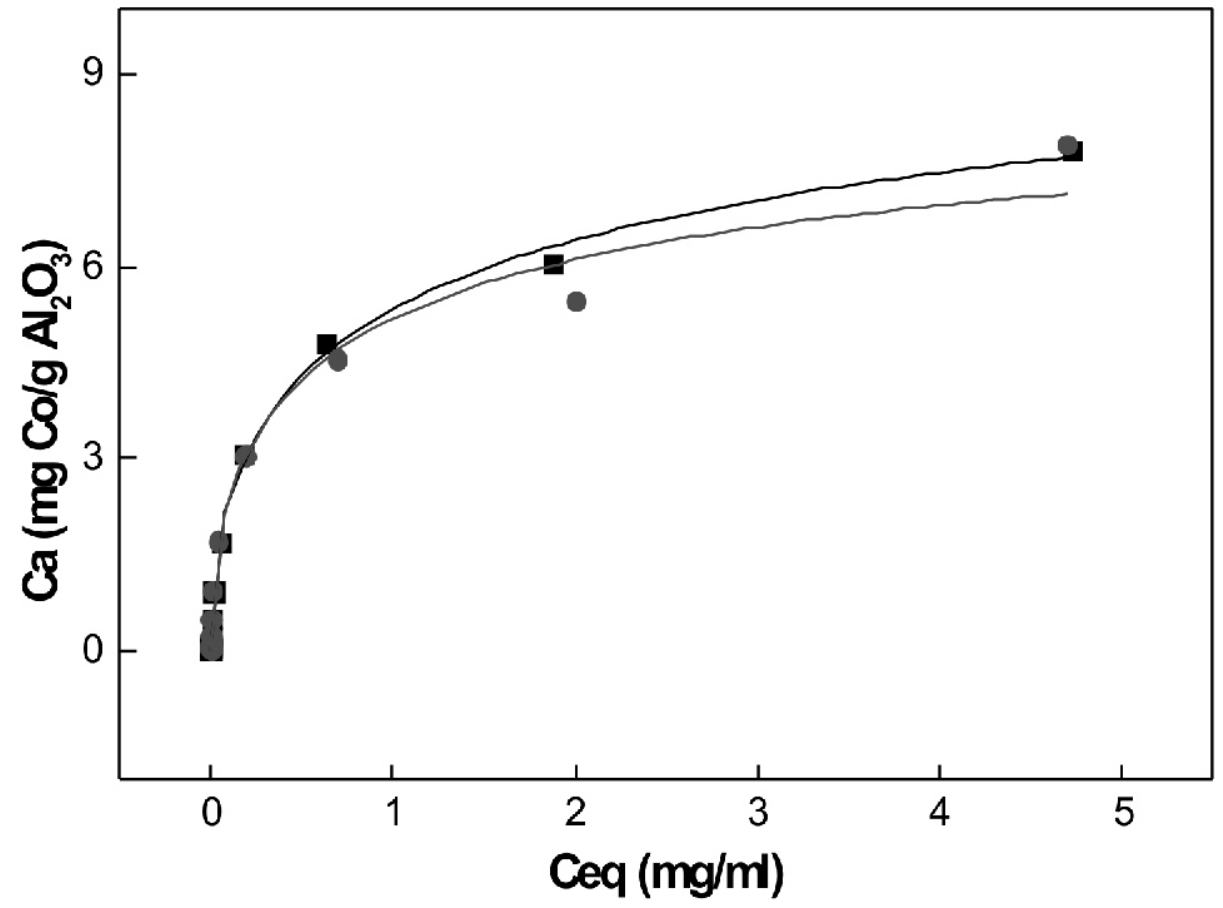

Figure 8. Room temperature adsorption isotherms of cobalt (CoCl) on alumina supports: (ロ) $\gamma-\mathrm{Al}_{2} \mathrm{O}_{3}(\mathrm{AK}) ;(\bullet), \gamma$ $\mathrm{Al}_{2} \mathrm{O}_{3}(\mathrm{RO})$. The lines represent the fitting of the experimental adsorption data to the isotherms derived from the equilibrium parameters. 


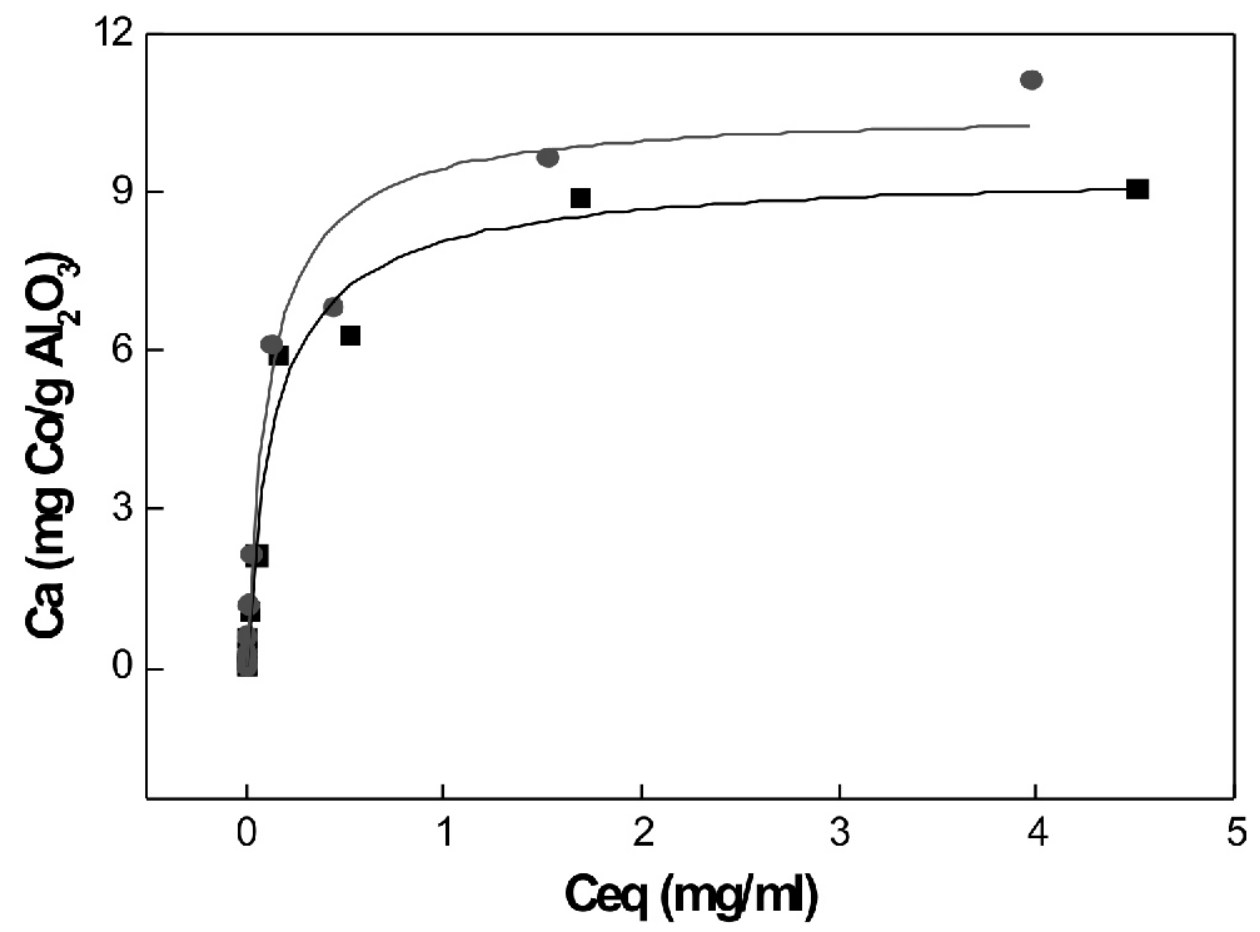

Figure 9. Room temperature adsorption isotherms of cobalt (CoAc) on alumina supports: (ロ) $\gamma-A_{2} O_{3}(A K)$; (•) $\gamma-\mathrm{Al}_{2} \mathrm{O}_{3}(\mathrm{RO})$. The lines represent the fitting of the experimental adsorption data to the isotherms derived from the equilibrium parameters.

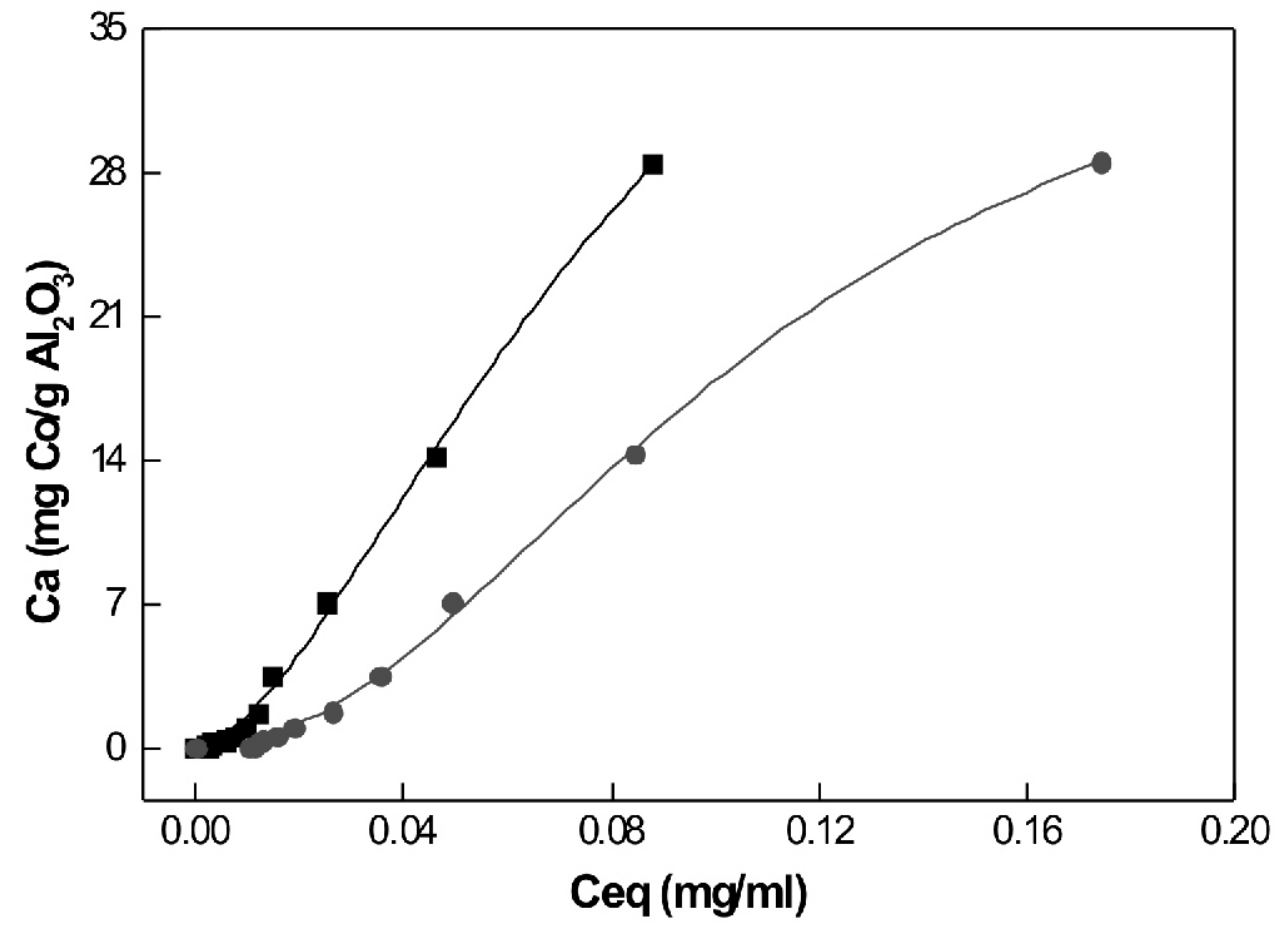

Figure 10. Room temperature adsorption isotherms of cobalt on $\gamma-\mathrm{Al}_{2} \mathrm{O}_{3}(\mathrm{PR}):(\bullet) \mathrm{CoAc}$; (•) CoCl. The lines represent the fitting of the experimental adsorption data to the isotherms derived from the equilibrium parameters. 


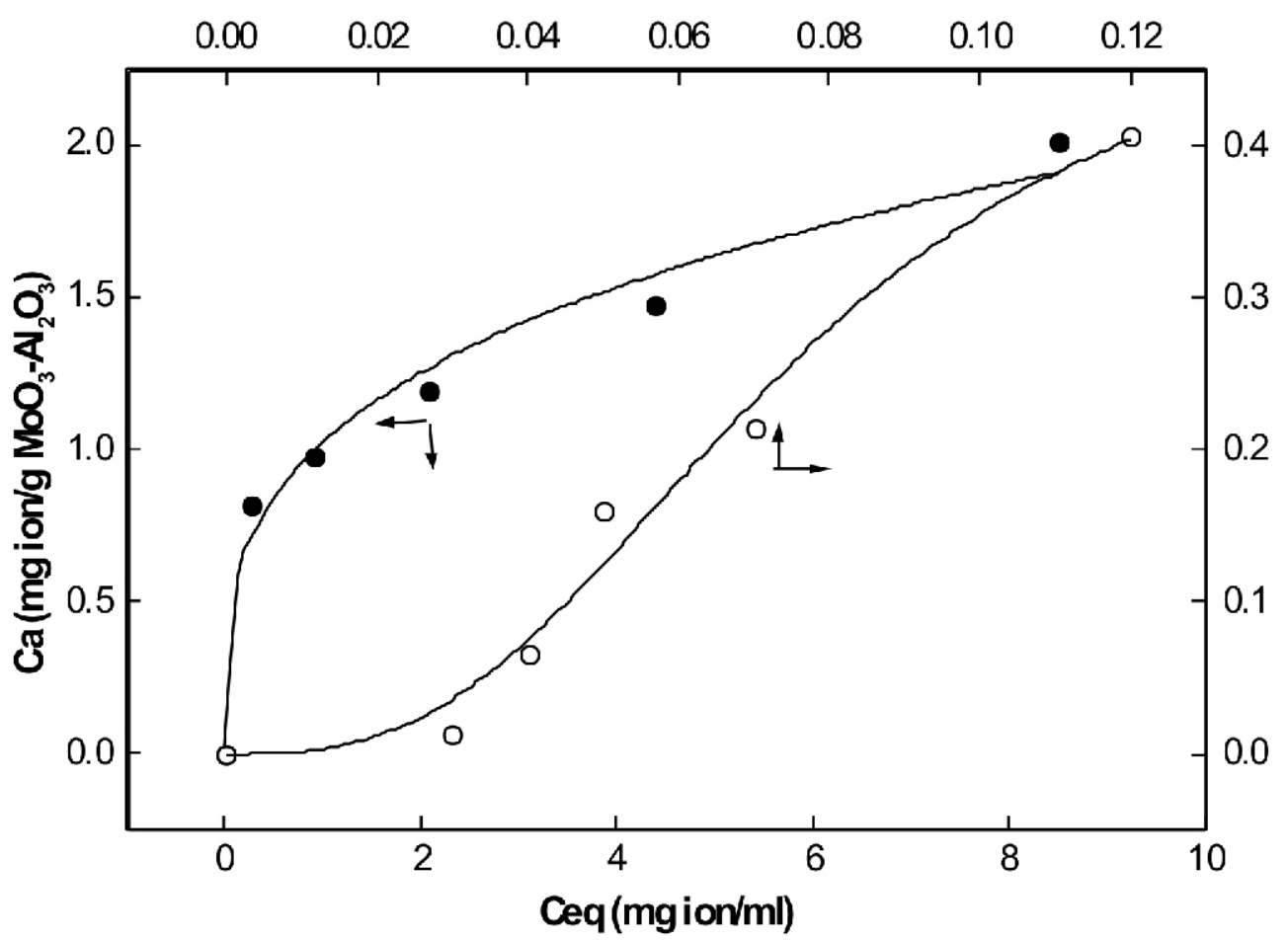

Figure 11. Room temperature adsorption isotherms of platinum and cobalt ions on $\mathrm{MoO}_{3} / \gamma-\mathrm{Al}_{2} \mathrm{O}_{3}(A K)$ : (•), Co (Pt); (०), Pt (Co). The lines represent the fitting of the experimental adsorption data to the isotherms derived from the equilibrium parameters.

exhibited a higher adsorption capacity than the AK and RO counterparts. Since these gave rise to an Stype shaped isotherm within the concentration range used, differences in impurity levels and in surface chemical groups of each alumina could well be responsible for this behavior. The curve shape found for $\mathrm{CoNi}, \mathrm{CoCl}$ and $\mathrm{CoCl}$ adsorption suggests that the adsorption sites in the $\mathrm{AK}$ y $\mathrm{RO}$ alumina are similar.

The adsorption isotherms of $\mathrm{Co}(\mathrm{Pt})$ and $\mathrm{Pt}(\mathrm{Co})$ on $\mathrm{MoO}_{3} / \gamma-\mathrm{Al}_{2} \mathrm{O}_{3}$ are shown in (Fig. 11). The isotherm for $\mathrm{Pt}(\mathrm{Co})$ belongs to the S-type; this shape is very different from the L type, which was found for the $\mathrm{Pt}$ adsorption on $\mathrm{MoO}_{3} / \mathrm{Al}_{2} \mathrm{O}_{3}$, Machuca et al (2001). The presence of $\mathrm{Co}$ (II) ion in solution may alter both the kinetics and extent of Pt adsorption. Similarly, the $\mathrm{Co}$ adsorption on $\mathrm{MoO}_{3} /$ alumina changed when Pt ion was also present in solution. In this case, the shape of the isotherm was of the L-type, which differs from the S-type found for the adsorption of $\mathrm{Co}$ (II) ions on $\mathrm{MoO}_{3}$ /alumina. In a previous work, Machuca et al (2001), it was observed that adsorbed, irrespective of the $\mathrm{Al}_{2} \mathrm{O}_{3}$ source used the adsorption sites on $\mathrm{MoO}_{3} / \gamma-\mathrm{Al}_{2} \mathrm{O}_{3}$, where the ionic species (Co(II) or Pt(IV)) were adsorbed, can be virtually the same in each case since the new surface is the $\mathrm{MoO}_{3}$ oxide deposited over the $\mathrm{Al}_{2} \mathrm{O}_{3}$ substrate.

The observed behavior can be explained in terms of the two types of isotherms (S and L), which imply lateral interactions between the $\mathrm{Pt}(\mathrm{IV})$ and $\mathrm{Co}(\mathrm{II})$ species in solution. As a consequence, the equilibrium adsorption capacity of the $\mathrm{MoO}_{3} / \mathrm{Al}_{2} \mathrm{O}_{3}$ surface may be modified by these interactions. In this sense, a reduction in the Co(II) ion adsorption capacity on $\mathrm{MoO}_{3}$ /alumina surface was observed when $\mathrm{Pt}(\mathrm{IV})$ ions were in solution and vice versa. Within the concentration range used, the equilibrium adsorption capacity ratio (with and without ions) was $8 / 1$ and $13 / 4$ for the $\mathrm{Co}$ and $\mathrm{Pt}$, respectively. This different behavior can be explained in terms of the equilibrium distribution of adsorbate species between the surface of the support and the liquid phase, which depends on the concentration and nature of the ions, temperature, the chemical nature 
of the support and the interface (liquid-solid) and ion-ion interactions, Giles et al. (1974). Consequently, when more than one adsorbate is present in solution, the interaction between different ions for the adsorption sites must be taken into account.

This assumption is reinforced by the observation that $\mathrm{Co}(\mathrm{II})$ and $\mathrm{Pt}(\mathrm{IV})$ ions will interact electrostatically with a molybdate phase bound to the surface. As a consequence of the simultaneous participation of the three species, the adsorption process is more complex. Since an S-type shaped isotherm was found within the concentration range used, this reflects the additive effect of the incorporated ion. Noble metal (Pt, $\mathrm{Ru}, \mathrm{Pd})-$ Mo/alumina samples prepared by Meriño et al. (2000) showed a decrease in the activity for the hydrodesulfurization reaction of dibenzothiophene when one monolayer of the $\mathrm{MoO}_{3}$-like phase was developed on the alumina substrate and, subsequently, $\mathrm{Pt}(\mathrm{IV})$ ions were adsorbed on the $\mathrm{MoO}_{3} / \mathrm{Al}_{2} \mathrm{O}_{3}$ system. However, a better activity of the catalysts can be obtained by keeping the Moloading below the monolayer capacity of the $\mathrm{Al}_{2} \mathrm{O}_{3}$ surface, Pinzon et al. (2006), Giraldo et al. (2008), these results confirm that both the monolayer of Mo species on the surface and the ion coimpregnation influence the adsorption process during the impregnation steps of noble metal-Mo/alumina samples.

In addition, Spanos \& Lycourghiotis (1994) have reported that mutual promotion exists in the adsorption of $\mathrm{Mo}(\mathrm{VI})$ and $\mathrm{Co}(\mathrm{II})$ ion species on $\mathrm{Al}_{2} \mathrm{O}_{3}$ in the 4.1-6.1 $\mathrm{pH}$ range; this was attributed to the strong lateral interactions exerted between $\mathrm{Mo}(\mathrm{VI})$ and $\mathrm{Co}$ (II) ions in solution. Finally, most of the adsorption isotherms for $\mathrm{PtCl}_{6}^{2-}$ ions reported in literature correspond to the $\mathrm{Pt} / \mathrm{Al}_{2} \mathrm{O}_{3}$ system, Lee \& Aris (1985), Gavriilidis et al. (1993), for which the effects of several inorganic and organic acids as competing agents on the deposition of Pt on alumina have been extensively investigated. Thus, Gavriilidis et al. (1993) and Papageorgiou et al. (1996) have reported the use of the modified Langmuir model to quantitatively describe transient adsorption studies of the Pt-citric acid system, which in turn also accounted for the effects of the solution and steric hindrance.

\subsection{Numerical Calculations}

For the quantitative description of the above isotherms, numerical calculations were carried out. For this purpose, different equations relating the equilibrium concentration in solution and the amount of adsorbed species were examined, Bourikas et al. (1996, 2006), Giles et al. (1974), Ruthven (1984). In this sense, the main goal was to obtain an expression or relationship that could be easily used to model the impregnation steps and to predict the concentration profile of the active component inside the pellet. The classic Langmuir expression was taken as the starting point for these studies. The Langmuir equation establishes a relationship between $\mathrm{Ca}$ and $\mathrm{C}_{\mathrm{eq}}$ by:

$$
C a_{e q}=\frac{K_{e} \cdot S \cdot C_{e q}}{1+K_{e} \cdot C_{e q}}
$$

where $\mathrm{K}_{\mathrm{e}}(\mathrm{ml} / \mathrm{mg})$ is the equilibrium adsorption constant; $\mathrm{S}$ (mg ion/g support) is the corresponding surface concentration at equilibrium, and $\mathrm{C}_{\mathrm{eq}}$ $(\mathrm{mg} / \mathrm{ml})$ is the solution concentration.

Other expressions such as those proposed by Giles, Kitchener, Henry and Freundlich were also used to quantitatively describe the relationship between $\mathrm{Ca}$ and $\mathrm{C}_{\mathrm{eq}}$, Pizzio et al. (1996), Giles et al. (1974), Ruthven (1984), Bearing in mind the assumption of these authors for type $\mathrm{S}$ isotherms, the expressions for Giles and Kitchener are:

$$
\begin{gathered}
C a_{e q}=\frac{K_{G} \cdot S \cdot C_{e q}^{x}}{1+K_{G} \cdot C_{e q}^{x}} \\
C a_{e q}=\frac{K_{1} \cdot S \cdot C_{e q} 10^{-k 1 \theta}}{1+K_{1} \cdot C_{e q} 10^{-k 1 \theta}}
\end{gathered}
$$

Where $\mathrm{K}_{\mathrm{G}}(\mathrm{ml} / \mathrm{mg}) \mathrm{x}$ is the Giles equilibrium adsorption constant, $\mathrm{S}$ is the saturation concentration ( $\mathrm{mg}$ ion/g support) at equilibrium; $\mathrm{x}$ is an exponential that describes the isotherm shape; $\mathrm{K}_{1}$ and $\mathrm{k}_{1}$ are constants, and $\theta=\mathrm{Ca} / \mathrm{S}$ is the fraction of adsorption sites occupied. The Giles and Kitchener expressions are related to the Lagmuir constant by $\mathrm{Ke}=\mathrm{K}_{\mathrm{G}} \mathrm{C}_{\mathrm{eq}}{ }^{\mathrm{x}-1}$ and $\mathrm{Ke}=\mathrm{K}_{1} 10^{-\mathrm{k} 1 \theta}$ respectively. 
Using a non-linear least-squares algorithm (Levenberg-Marquart), the equilibrium adsorption parameters for each system and equation were calculated from the fitting of the equilibrium data. This procedure was accomplished by minimizing the $\chi^{2}$ parameter. The group of parameters showing the best fit to the experimental isotherm is summarized in the (Table 3). Although in most cases the difference between the equations is very small, the choice basically depends on the simplicity of the mathematical model chosen to describe the impregnation process.

From Figs. 5 and 6 and Table 3, it is clear that the $\gamma$ $\mathrm{Al}_{2} \mathrm{O}_{3}$ (AK) sample shows a slightly higher adsorption capacity than its $\gamma-\mathrm{Al}_{2} \mathrm{O}_{3}$ (RO and PR) counterparts for Mo ion adsorption, although this difference is clearer in the SoMo isotherm. All the $\gamma$ $\mathrm{Al}_{2} \mathrm{O}_{3}$ samples studied exhibited a higher affinity for polymeric molybdate than for monomeric ions. This difference may be due to the presence of different impurities and the different amount and types of sites for adsorption (hydroxyl types) on those surfaces, since the textural parameters and $\mathrm{pH}_{\mathrm{ZPC}}$ values are very close, Giordano et al. (1975), Adachi et al. (1996). The $\gamma-\mathrm{Al}_{2} \mathrm{O}_{3}(\mathrm{AK})$ sample has a higher $\mathrm{S}$ (mg Mo/g alumina) value than its $\gamma-\mathrm{Al}_{2} \mathrm{O}_{3}(\mathrm{RO}$ and PR) counterparts.

At low concentration values, up to $5 \mathrm{mg} / \mathrm{mL}$, the isotherms show a Henry-type behavior. Thus, the Henry constant for the AK-type $\mathrm{Al}_{2} \mathrm{O}_{3}$ sample is higher than for the RO- and PR-type $\gamma-\mathrm{Al}_{2} \mathrm{O}_{3}$ counterparts. This observation again suggests a higher availability of adsorption sites on the AKtype $\gamma-\mathrm{Al}_{2} \mathrm{O}_{3}$ than on the RO- and PR-type $\gamma-\mathrm{Al}_{2} \mathrm{O}_{3}$ surfaces.

The fitting parameters, the saturation coverage of Mo, and the equilibrium constant, calculated from the Giles, Langmuir and Freundlich model are

Table 3. Equilibrium adsorption parameters derived from the fittings

\begin{tabular}{cccccccccccc}
\hline \multirow{2}{*}{ System } & \multicolumn{4}{c}{ Giles } & \multicolumn{4}{c}{ Langmuir } & \multicolumn{3}{c}{ Freundlich } \\
\cline { 2 - 11 } & $\mathrm{K}_{\mathrm{G}}$ & $\mathrm{S}$ & $\mathrm{X}$ & $\chi^{2}$ & $\mathrm{Ke}$ & $\mathrm{S}$ & $\chi^{2}$ & $\mathrm{~A}$ & $\mathrm{~B}$ & $\chi^{2}$ \\
\hline $\mathrm{AHM} / \mathrm{Al}_{2} \mathrm{O}_{3}(\mathrm{AK})$ & 0.0658 & 119.00 & 1.45 & 15.50 & 0.109 & 140 & 25.50 & 22.75 & 0.455 & 110 \\
$\mathrm{AHM} / \mathrm{Al}_{2} \mathrm{O}_{3}(\mathrm{RO})$ & 0.0481 & 100.00 & 1.32 & 4.09 & 0.059 & 130 & 6.11 & 10.58 & 0.622 & 19.2 \\
$\mathrm{AHM} / \mathrm{Al}_{2} \mathrm{O}_{3}(\mathrm{PR})$ & 0.1692 & 73.27 & 1.28 & 2.62 & 0.209 & 80 & 3.15 & 18.550 & 0.408 & 25.6 \\
$\mathrm{SoMo} / \mathrm{Al}_{2} \mathrm{O}_{3}(\mathrm{AK})$ & 0.2460 & 23.26 & 0.87 & 0.18 & 0.253 & 21 & 0.20 & 5.249 & 0.411 & 1.07 \\
$\mathrm{SoMo} / \mathrm{Al}_{2} \mathrm{O}_{3}(\mathrm{RO})$ & 0.2780 & 5.99 & 0.55 & 0.02 & 0.393 & 3.9 & 0.05 & 1.308 & 0.335 & 0.04 \\
$\mathrm{SoMo} / \mathrm{Al}_{2} \mathrm{O}_{3}(\mathrm{PR})$ & 0.6670 & 8.50 & 1.49 & 0.07 & 0.579 & 9.4 & 0.20 & 3.070 & 0.366 & 1.63 \\
$\mathrm{CoNi} / \mathrm{Al}_{2} \mathrm{O}_{3}(\mathrm{AK})$ & 0.2140 & 28.62 & 0.41 & 0.03 & 2.380 & 8.2 & 0.32 & 4.899 & 0.353 & 0.04 \\
$\mathrm{CoNi} / \mathrm{Al}_{2} \mathrm{O}_{3}(\mathrm{RO})$ & 0.5960 & 12.05 & 0.38 & 0.01 & 5.838 & 5.9 & 0.25 & 4.260 & 0.270 & 0.04 \\
$\mathrm{CoNi} / \mathrm{Al}_{2} \mathrm{O}_{3}(\mathrm{PR})$ & 1.3760 & 9.88 & 0.97 & 0.05 & 1.431 & 9.7 & 0.05 & 4.392 & 0.383 & 1.03 \\
$\mathrm{CoCl} / \mathrm{Al}_{2} \mathrm{O}_{3}(\mathrm{AK})$ & 0.7720 & 12.22 & 0.51 & 0.02 & 3.654 & 7.5 & 0.20 & 4.913 & 0.319 & 0.12 \\
$\mathrm{CoCl} / \mathrm{Al}_{2} \mathrm{O}_{3}(\mathrm{RO})$ & 1.1180 & 9.83 & 0.55 & 0.17 & 3.359 & 7.3 & 0.42 & 4.784 & 0.310 & 0.10 \\
$\mathrm{CoCl} / \mathrm{Al}_{2} \mathrm{O}_{3}(\mathrm{PR})$ & 92.300 & 39.63 & 2.04 & 0.10 & - & - & - & 252.0 & 1.231 & 1.43 \\
$\mathrm{CoAc} / \mathrm{Al}_{2} \mathrm{O}_{3}(\mathrm{AK})$ & 5.8950 & 9.45 & 0.92 & 0.29 & 7.338 & 9.2 & 0.26 & 6.680 & 0.294 & 1.25 \\
$\mathrm{CoAc} / \mathrm{Al}_{2} \mathrm{O}_{3}(\mathrm{RO})$ & 1.9430 & 13.63 & 0.56 & 0.21 & 8.636 & 10 & 0.49 & 8.142 & 0.280 & 0.63 \\
$\mathrm{CoAcl} / \mathrm{Al}_{2} \mathrm{O}_{3}(\mathrm{PR})$ & 47.820 & 58.87 & 1.61 & 0.18 & - & - & - & 547.6 & 1.210 & 0.53 \\
$\mathrm{Co}-(\mathrm{Pt}) / \mathrm{MoO}_{3} / \mathrm{Al}_{2} \mathrm{O}_{3}(\mathrm{AK})$ & - & - & - & - & 1.426 & 1.9 & 0.06 & 1.023 & 0.291 & 0.01 \\
$\mathrm{Pt}-(\mathrm{Co}) / \mathrm{MoO}_{3} / \mathrm{Al}_{2} \mathrm{O}_{3}(\mathrm{AK})$ & 1535.8 & 0.51 & 2.82 & $7 \mathrm{E}-4$ & - & - & - & 8.144 & 1.403 & $1 \mathrm{E}-3$ \\
\hline
\end{tabular}


shown in Table 3 . The close values of $\mathrm{x}(1.45,1.32$ and 1.28 for AHM adsorption) indicate that the shape of the curves is quite similar for all three aluminas. There are differences between the SoMo isotherms on alumina, reflected in the parameter values. These results lie in the same range as many others reported in the literature. At this juncture it should be emphasized that the reported values for $\mathrm{S}$ and $\mathrm{K}_{\mathrm{e}}$ (Langmuir model) for the adsorption of molybdenum on alumina surfaces are scattered over broad ranges. Thus, Mo saturation coverages from 50 to $156 \mathrm{mg} \mathrm{Mo} / \mathrm{g}$ alumina and adsorption equilibrium constants from $1.9 \times 10-4$ to $1.65 \mathrm{ml} / \mathrm{mg}$ Mo can be found in the literature, van Veen et al. (1987), Giles et al. (1974), Gavriilidis et al. (1993), Pizzio et al. (1996). Although the chemical properties associated with the presence of different levels of impurities may alter the proportion of adsorption sites, textural properties may also contribute to exacerbating the observed differences.

Table 3 and Figs. 7-10 show that the $\mathrm{Co} / \gamma-\mathrm{Al}_{2} \mathrm{O}_{3}$ systems display almost identical L-shaped isotherms, except for $\mathrm{CoAc}$ and $\mathrm{CoCl}$ adsorptions on PR alumina, which exhibit an $\mathrm{S}$ type. This type of behavior suggests that either the same type of adsorption sites for $\mathrm{Co}$ are available on the $\gamma-\mathrm{Al}_{2} \mathrm{O}_{3}$ surface or that a similar deposition process is operative along the impregnation and drying steps, irrespective of the second ion in solution. For PR-type alumina and $\mathrm{CoCl}$ and $\mathrm{CoAc}$ systems, the Langmuir model obviously did not apply; however, the Giles equation revealed an appropriate fitting of the adsorption data. Within the $\mathrm{C}_{\text {eq }}$ concentration range explored, a stronger adsorption of $\mathrm{Co}$ (II) ions on PR-type alumina than for the other two aluminas was found.

By contrast, the two $\mathrm{Pt}(\mathrm{Co}) / \mathrm{MoO}_{3} / \gamma-\mathrm{Al}_{2} \mathrm{O}_{3}$ and $\mathrm{Co}(\mathrm{Pt}) / \mathrm{MoO}_{3} / \gamma-\mathrm{Al}_{2} \mathrm{O}_{3}$ samples showed the opposite adsorption behavior. The data can be satisfactorily described by the Freundlich and Giles equations respectively (Fig. 11 and Table 3 ). Saturation values of $2.0 \mathrm{mg} \mathrm{Co} / \mathrm{g} \mathrm{MoO}_{3}-\mathrm{Al}_{2} \mathrm{O}_{3}$ and $0.4 \mathrm{mg} \mathrm{Pt} / \mathrm{g} \mathrm{MoO}_{3}-\mathrm{Al}_{2} \mathrm{O}_{3}$ for the AK-type substrate were derived from the fitting. These values are lower than the adsorption data reported for $\mathrm{Pt} / \gamma$ -
$\mathrm{Al}_{2} \mathrm{O}_{3}$ catalysts. This monometallic system showed values between 21 to $56 \mathrm{mg} \mathrm{Pt} / \mathrm{g} \mathrm{Al}_{2} \mathrm{O}_{3}$ (110-290 $\left.\mu \mathrm{mol} \mathrm{H}_{2} \mathrm{PtCl}_{6} / \mathrm{g} \mathrm{Al}_{2} \mathrm{O}_{3}\right)$ and 0.56 to 159 $\mathrm{ml} / \mathrm{mg} \mathrm{Pt}\left(110-31000 \mathrm{l} / \mathrm{mol} \mathrm{H}_{2} \mathrm{PtCl}_{6}\right)$ for the surface saturation coverage and the equilibrium adsorption constant, $\mathrm{K}_{\mathrm{e}}$, respectively, Lee \& aris (1985), Papageorgiou et al. (1996). The large difference observed in the saturation values for $\mathrm{Pt}$ can be explained in terms of the notion that most of the adsorption sites are located on the alumina surface, and in turn disappear upon molybdenum incorporation and interaction with the ion in solution. Some discrepancies may also arise from the experimental conditions of the impregnation process used in the adsorption step.

\section{Conclusions}

The extent of Mo adsorption on the $\gamma-\mathrm{Al}_{2} \mathrm{O}_{3}$ surface depended on the type of molybdate species (tetrahedral and octahedral) in solution. Moreover, the adsorption process suggested that polymeric and monomeric species are present in the wet, dry and calcined states, since surface groups and alumina impurities can modify the adsorption process. The $\gamma-\mathrm{Al}_{2} \mathrm{O}_{3}(\mathrm{AK})$ sample showed a slightly higher adsorption capacity for Mo than its $\gamma-\mathrm{Al}_{2} \mathrm{O}_{3}(\mathrm{RO}$ and PR) counterparts. At low concentration values (until $5 \mathrm{mg} / \mathrm{ml}$ ), the Mo isotherms were almost linear (Henry-type behavior), with the Henry constant for the $\mathrm{Al}_{2} \mathrm{O}_{3}$ (AK) higher than for the other $\gamma-\mathrm{Al}_{2} \mathrm{O}_{3}$. This observation suggests a higher availability of adsorption sites on the $\gamma-\mathrm{Al}_{2} \mathrm{O}_{3}(\mathrm{AK})$ than on the $\gamma$ $\mathrm{Al}_{2} \mathrm{O}_{3}(\mathrm{RO}$ and $\mathrm{PR})$ surface.

For Co systems, it was observed that: (a) for Co adsorption, the same sites are present on the alumina surface when different precursors are used; (b) the shape of the adsorption isotherm of Pt on $\mathrm{MoO} 3 / \gamma-\mathrm{Al}_{2} \mathrm{O}_{3}$ surface changes from the $\mathrm{S}$ - to the L-type; (c) since L- and S-shaped isotherms were found for the $\mathrm{Co} / \gamma-\mathrm{Al}_{2} \mathrm{O}_{3}$ and $\mathrm{Co}-\mathrm{MoO}_{3} / \gamma$ $\mathrm{Al}_{2} \mathrm{O}_{3}$ systems respectively, the adsorption of $\mathrm{Co}$ species was altered by the $\mathrm{MoO}_{3} / \gamma-\mathrm{Al}_{2} \mathrm{O}_{3}$ substrate. 


\section{Acknowledgements}

Machuca-Martinez gratefully acknowledges COLCIENCIAS, UIS and UNIVALLE (Colombia) and ICP-CSIC (Spain) for a fellowship and financial support. The alumina supports used in the present work were kindly supplied by Akzo-Nobel (The Netherlands), Rhodia (France) and Procatalyse (France).

\section{References}

Achchar, M., Lamonier, C., Ezzamarty, A., Lakhdar, M., Leglise, J., \& Payen, E. (2009). New apatite-based supports prepared by industrial phosphoric acid for HDS catalyst synthesis. Comptes Rendus Chimie 12 (6-7), 677-682.

Adachi, M., Contescu, C., \& Schwarz, J. A. (1996). The Use of Proton Affinity Distributions for the Characterization of Active Sites of Alumina-Supported Co-Mo Catalysts. Journal of Catalysis 158 (2), 411-419.

Al-Dalama, K., Aravind, B., \& Stanislaus, A. (2005). Influence of complexing agents on the adsorption of molybdate and nickel ions on alumina. Applied Catalysis A-General 296 (1), 4953.

Baumgarten, E., \& Kirchhausen-Dusing, U. (1997). Sorption of Metal Ions on Alumina. Journal of Colloid and Interface Science 194 (1), 1-9.

Bejenaru, N., Lancelot, C., Blanchard, P., Lamonier, C., Rouleau, L., Payen, E., Dumeignil, F., \& Royer, S. (2009). Synthesis, Characterization, and Catalytic Performances of Novel CoMo Hydrodesulfurization Catalysts Supported on Mesoporous Aluminas. Chemistry of materials 21 (3), 522-533.

Baldovino-Medrano, V.G., Giraldo, S.A., \& Centeno, A. (2009). The functionalities of Pt-Mo catalysts in hydrotreatment reactions, Fuel, In Press, DOI: 10.1016/j.fuel.2009.12.002.
Bergwerff, J.A., Visser, T., \& Weckhuysen, B.M. (2008). On the interaction between Co- and Mocomplexes in impregnation solutions used for the preparation of A12O3-supported HDS catalysts: A combined Raman/UV-vis-NIR spectroscopy study. Catalysis Today 130 (1), 117-125.

Bourikas, K., Goula G.A., \& Lycourghiotis, A. (1998). Kinetics of Deposition of the Mo-Oxo Species on the Surface of $\gamma$-Alumina. Langmuir 14 (17), 48194826.

Bourikas, K., Kordulis, C., \& Lycourghiotis, A. (2006). The Role of the Liquid-Solid Interface in the Preparation of Supported Catalysts. Catalysis Reviews Science and Engineering 48 (4), 363 444.

Bourikas, K., Matralis, H.K., Kordulis, Ch., \& Lycourghiotis, A. (1996). Mechanisms of Deposition of Species Containing Catalytically Active Ions on the Oxidic Support/Electrolytic Solution Interfaces: A Unified Approach Based on the Two-pk/One-Site and Triple-Layer Models. Journal of Physical Chemistry 100 (28), 1171111719.

Butz, T., Vogdt, C., Lerf, A., \& Knözinger, H. (1989). Time differential perturbed angular correlation of $\gamma$-rays emitted from ${ }^{99} \mathrm{Mo} \rightarrow{ }^{99} \mathrm{Tc}$ in molybdenum-based catalysts : The nature of molybdate species in molybdena/alumina catalysts. Journal of Catalysis, 116 (1), 31-48.

Chianelli, R.R., Berhault, G., \& Torres, B. (2009). Unsupported transition metal sulfide catalysts: 100 years of science and application. Catalysis Today 147 (3-4), 275-286

Chu, T. W., Du J. Z., \& Tao., Z. Y. (1997). Adsorption of $\mathrm{H}^{+}, \mathrm{OH}-$ and Background Electrolyte Ions on Alumina-point of Zero Charge, Triple Layer Model (TLM) Parameters and Thermodynamic Parameters. Adsorption Science and Technology 15 (1), 455-463 
De Lacaillerie, JBD., \& Gan, Z. (2007). MAS NMR strategies for the characterization of supported molybdenum catalysts. Applied magnetic resonance 32 (4), 499-511.

de Wilmar, D. M., \& Clause, O. (1998). Adaptation of 27Al CP/MAS NMR to the Investigation of the Adsorption of Molybdate Ions at the $\gamma-\mathrm{Al}_{2} \mathrm{O}_{3}$ /Water Interface. Journal of Physical Chemistry B 102 (36), 70237027.

Duan, A.J., Wan, G.F., Zhao, Z., Xu, C.M., Zheng, Y.Y., Zhang, Y., Dou, T., Bao, X.J., \& Chung, K. (2007). Characterization and activity of Mo supported catalysts for diesel deep hydrodesulphurization. Catalysis Today 119 (14), 13-18.

Eliche-Quesada, D., Rodriguez-Castellon, E., \& Jimenez-Lopez, A. (2007). Hydrodesulfurization activity over supported sulfided ruthenium catalysts. Influence of the support, Microporous and Mesoporous Materials 99 (3), 268-278.

Fournier, M., Louis, C., Che, M., Chaquin, P., \& Masure, D. (1989). Polyoxometallates as models for oxide catalysts : Part I. An UV-visible reflectance study of polyoxomolybdates: Influence of polyhedra arrangement on the electronic transitions and comparison with supported molybdenum catalysts. Journal of Catalysis 119(2), 400-414.

Frizi, N., Blanchard, P., Payen, E., Baranek, P., Rebeilleau, M., Dupuy, C., \& Dath, JP. (2008). Genesis of new HDS catalysts through a careful control of the sulfidation of both Co and Mo atoms: Study of their activation under gas phase. Catalysis Today 130 (2-4), 272-282.

Gajardo, P., Grange, P., \& Delmon, B. (1980). Structure of oxide CoMo/[gamma]-A1203 hydrodesulfurization catalysts: An XPS and DRS study. Journal of Catalysis 63 (1), 201-216.

Gavriilidis, A., Varma, A., \& Morbidelli, M. (1993). Optimal distribution of catalyst in pellets. Catalysis Reviews - Science and Engineering 35 (3), 399-456.
Gesari, S., Irigoyen, B., \& Juan, A. (1997). Estudio estructural del $\mathrm{MoO} 3$ y sus planos cristalinos. Quím. Nova 20 (1), 99-102.

Giles, C. H., Smith, D., \& Huitson, A. (1974). A general treatment and classification of the solute adsorption isotherm. I. Theoretical, Journal of Colloid and Interface Science 47 (3), 755-765.

Giordano, N., Bart, J. C. J., Vaghi, A., Castellan, A., \& Martinotti, G. (1975). Structure and catalytic activity of $\mathrm{MoO}_{3}$ [middle dot] $\mathrm{Al}_{2} \mathrm{O}_{3}$ systems : I. Solid-state properties of oxidized catalysts. Journal of Catalysis 36 (1), 81-92.

Giraldo, S.A., Pinzon, M.H., \& Centeno, A. (2008). Behavior of catalysts with rhodium in simultaneous hydrodesulfurization and hydrogenation reactions. Catalysis Today 133 (1), 239-243.

Griboval, A., Blanchard, P., Payen, E., Fournier, M., \& Dubois, J.L. (1998). Alumina supported HDS catalysts prepared by impregnation with new heteropolycompounds. Comparison with catalysts prepared by conventional Co-Mo-P coimpregnation. Catalysis Today 45 (1-4), 277283.

Hachiya, K., Sasaki, M., Saruta, Y., Mikami, N., \& Yasunaga, T. (1984). Static and kinetic studies of adsorption-desorption of metal ions on a gamma.-alumina surface. 1. Static study of adsorption-desorption. Journal Physical Chemistry 88(1), 2327.

Iannibello, A., \& Mitchell, P.C.H. (1979). Preparative Chemistry of CobaltMolybdenum/Alumina Catalysts. Studies in Surface Science and Catalysis, 3, 469-478

Jiang, Z., Huang, W., Zhao, H., Zhang, Z., Tan, D., \& Bao, X. (2008). Preferential occupation of molybdenum on the thin alumina film: Characterization by CO titration. Catalysis Today, $131(1-4), 28-34$. 
Kim, D. S., Ostromecki, M., Wachs, I. E., Kohler S. D., \& Ekerdt. J. G. (1995). Preparation and characterization of $\mathrm{WO}_{3} / \mathrm{SiO}_{2}$ catalysts. Catalysis Letters 33 (3-4), 209-212.

Klimova, T., Mendoza Vara, P., \& Puente Lee, I. (2009). Development of new NiMo/[gamma]alumina catalysts doped with noble metals for deep HDS, Catalysis Today, In Press, DOI: 10.1016/j.cattod.2009.08.003.

Klimova, T., Solis-Casados, D., \& Ramirez, J. (1998). New selective Mo and NiMo HDS catalysts supported on $\mathrm{Al}_{2} \mathrm{O}_{3}-\mathrm{MgO}(\mathrm{x})$ mixed oxides. Catalysis Today 43 (1-2), 135-146.

Komiyama, M. (1985). Design and Preparation of Impregnated Catalysts. Catalysis Reviews Science and Engineering 27 (2), 341372.

Kubicka, D., \& Kaluza, L. (2010). Deoxygenation of vegetable oils over sulfided Ni, Mo and NiMo catalysts. Applied Catalysis A: General 372 (2), 199-208.

Kubota, T., Rinaldi, N., Okumura, K., Honma, T., Hirayama, S., \& Okamoto, Y. (2010). In situ XAFS study of the sulfidation of Co$\mathrm{Mo} / \mathrm{B}_{2} \mathrm{O}_{3} / \mathrm{Al}_{2} \mathrm{O}_{3}$ hydrodesulfurization catalysts prepared by using citric acid as a chelating agent. Applied Catalysis A: General 373 (1-2), 214-221.

Kurhinen, M., \& Pakkanen, T.A. (2000). CoMo/alumina prepared from carbonyl precursors: DRIFT, TPR and HDS studies. Applied Catalysis A: General 192 (1), 97-103.

Lamonier, C., Martin, C., Mazurelle, J., Harle, V., Guillaume, D., \& Payen, E. (2007). Molybdocobaltate cobalt salts: New starting materials for hydrotreating catalysts. Applied Catalysis B: Environmental 70 (1-4), 548-556.

Lee, S.Y., \& Aris, R. (1985). The Distribution of Active ingredients in Supported Catalysts Prepared by Impregnation. Catalysis Reviews Science and Engineering 27 (2), 207340.
Luthra, N. P., \& Cheng, W-C. (1987). Molybdenum-95 NMR study of the adsorption of molybdates on alumina. Journal of Catalysis 107 (1), 154-160.

Machuca, F., Giraldo de Leon, S., Centeno, A., \& Fierro, J. L. G. (2001). Pt- (and Co-) Promoted Molybdena-Alumina Catalysts: Analysis of the Impregnation Steps. Journal of Colloid and Interface Science 237 (2), 290-293.

Merino, L. I., Centeno, A., \& Giraldo, S. A. (2000) Influence of the activation conditions of bimetallic catalysts $\mathrm{NM}-\mathrm{Mo} /[$ gamma $]-\mathrm{Al}_{2} \mathrm{O}_{3} \quad(\mathrm{NM}=\mathrm{Pt}, \mathrm{Pd}$ and $\mathrm{Ru}$ ) on the activity in HDT reactions. Applied Catalysis A: General 197 (1), 61-68.

Mestl, G.A, \& Srinivasan, T.K.K. (1998). Raman spectroscopy of monolayer-type catalysts: Supported molybdenum oxides. Catalysis Reviews - Science and Engineering 40 (4), 451570.

Navarro, R.M., Pawelec, B., Trejo, J.M., Mariscal, R., \& Fierro, J. L. G. (2000). Hydrogenation of Aromatics on Sulfur-Resistant PtPd Bimetallic Catalysts. Journal of Catalysis 189 (1), 184-194.

Mulcahy, F. M., Houalla, M., \& Hercules, D. M. (1987). The effect of the isoelectric point on the adsorption of molybdates on fluoride-modified aluminas. Journal of Catalysis 106 (1), 210-215.

Pashigreva, A. V., Klimov, O.V., Bukhtiyarova, G. A., Kochubey, D. I., Prosvirin, I. P., Chesalov, Y. A., Zaikovskii, V. I., \& Noskov, A. S. (2009). High-active hydrotreating catalysts for heavy petroleum feeds: Intentional synthesis of CoMo sulfide particles with optimal localization on the support surface. Catalysis Today In Press, DOI: 10.1016/j.cattod.2009.08.021.

Papageorgiou, P., Price, D. M., Gavriilidis, A., \& Varma, A. (1996). Preparation of Pt/[gamma]A12O3 Pellets with Internal Step-Distribution of Catalyst: Experiments and Theory. Journal of Catalysis 158(2), 439-451. 
Pinzon, M.H., Centeno, A., \& Giraldo, S.A. (2006). Role of Pt in high performance Pt-Mo catalysts for hydrotreatment reactions. Applied Catalysis A-General 302 (1), 118-126.

Pizzio, L.R., Vázquez, P.G., Cáceres, C.V., \& Blanco, M.N. (1996). Adsorption and impregnation of alumina with molybdenum or tungsten solutions. Adsorption Science and Technology 13 (3), 165-176.

Plyuto, Yu. V., Babich, I. V., Plyuto, I. V., Van Langeveld, A. D., \& Moulijn, J. A. (1997). Synthesis and characterization of molybdenum(VI) oxo-species on the surface of fumed alumina and silica. Colloids and Surfaces A: Physicochemical and Engineering Aspects, $125(2-3), 225-230$.

Ramirez, J., Cedeno, L., \& Busca, G. (1999). The Role of Titania Support in Mo-Based Hydrodesulfurization Catalysts. Journal of Catalysis 184 (1), 59-67.

Regalbuto, J. R., Navada, A., Shadid, S., Bricker, M. L., \& Chen, Q. (1999). An Experimental Verification of the Physical Nature of $\mathrm{Pt}$ Adsorption onto Alumina. Journal of Catalysis $184(2), 335-348$.

Roukoss, C., Laurenti, D., Devers, E., Marchand, K., Massin, L., \& Vrinat, M. (2009). Hydrodesulfurization catalysts: Promoters, promoting methods and support effect on catalytic activitie. Comptes Rendus Chimie 12 (6-7), 683-691.

Ruckenstein, E., \& Karpe, P. (1989). Control of metal distribution in supported catalysts by $\mathrm{pH}$, ionic strength, and coimpregnation. Langmuir 5 (6), 1393-1407.

Schmal, M., Baldanza, M. A. S., \& Vannice, M. A. (1999). $\mathrm{Pd}-\mathrm{xMo} / \mathrm{Al}_{2} \mathrm{O}_{3}$ Catalysts for NO Reduction by CO. Journal of Catalysis 185 (1), 138-151.

Semagina, N., Kiwi-Minsker, L. (2009). Recent Advances in the Liquid-Phase Synthesis of Metal Nanostructures with Controlled Shape and Size for Catalysis. Catalysis Reviews- Science and Engineering 51 (2), 147217.
Siri, G.J., Morales, M.I., Blanco, M.N., \& Thomas, H.J. (1985). The $\mathrm{MoCoAl}_{2} \mathrm{O}_{3}$ system. I. Molybdenum adsorption on $\mathrm{CoAl}_{2} \mathrm{O}_{3}$. Applied Catalysis 19(1), 49-63.

Spanos, N., \& Lycourghiotis, A. (1994). Mechanism of codeposition of Mo(VI) species and $\mathrm{Co}^{2+}$ ions on the $\gamma$-alumina surface. Langmuir $10(7), 2351-2362$.

Spanos, N., Vordonis, L., Kordulis, Ch., \& Lycourghiotis, A. (1990). Molybdenum-oxo species deposited on alumina by adsorption : I. Mechanism of the Adsorption. Journal of Catalysis 124 (2), 301-314.

Tamura, H., Katayama, N., \& Furuichi, R. (1997). The $\mathrm{Co}^{2+}$ Adsorption Properties of $\mathrm{Al}_{2} \mathrm{O}_{3}, \mathrm{Fe}_{2} \mathrm{O}_{3}$, $\mathrm{Fe}_{3} \mathrm{O}_{4}, \mathrm{TiO}_{2}$, and $\mathrm{MnO}_{2}$ Evaluated by Modeling with the Frumkin Isotherm. Journal of Colloid and Interface Science 195 (1), 192-202.

Tewari, P.H., Campell A.B., \& Lee, W. (1975). Adsorption of $\mathrm{Co} 2+$ by Oxides from Aqueous Solution. Canadian Journal of Chemistry 50 (11), 16421648.

van Veen, J.A.R., Hendriks, P.A.J.M., Romers, E.J.G.M., \& Andrea, R.R. (1990). Chemistry of phosphomolybdate adsorption on alumina surfaces. 1. The molybdate/alumina system. Journal of Physical Chemistry 94 (13), 5275-5282.

Tomii, V., \& Simeon, V. (1999). Ion association in aqueous solutions of strong electrolytes: a UVVis spectrometric and factor-analytical study. Physical Chemistry Chemical Physics 1 (2), 299-302.

van Veen, J. A. R., de Wit, H., Emeis, C. A., \& Hendriks, P. A. J. M. (1987). On the adsorption of heptamolybdate ions on [gamma] $-\mathrm{Al}_{2} \mathrm{O}_{3}$ and $\mathrm{TiO}_{2}$. Journal of Catalysis 107 (2), 579-582.

Vissenberg, M.J., Joosten, L.J.M., Heffels, M.M.E.H., van Welsenes, A.J., de Beer, V.H.J., van Santen, R.A., \& van Veen, J.A.R. (2000). Tungstate versus Molybdate Adsorption on Oxidic Surfaces: A Chemical Approach. Journal of Physical Chemistry B 104(35), 84568461. 
Wang, L., \& Keith Hall, W. (1982). The preparation and genesis of molybdena-alumina and related catalyst systems. Journal of Catalysis $77(1), 232-241$.

Weber R. S. (1995). Effect of Local Structure on the UV-Visible Absorption Edges of Molybdenum Oxide Clusters and Supported Molybdenum Oxides. Journal of Catalysis 151 (2), 470-474.

Weigold, H. (1983). The nature of molybdenum oxide species mounted on alumina: An oligomer model. Journal of Catalysis, 83 (1), 85-98.

Xiong, G., Feng, Z., Li, J., Yang, Q., Ying, P., Xin Q., \& Li, C. (2000). UV Resonance Raman Spectroscopic Studies on the Genesis of Highly Dispersed Surface Molybdate Species on $\gamma$ Alumina. Journal of Physical Chemistry. B 104 (15), 35813588. 